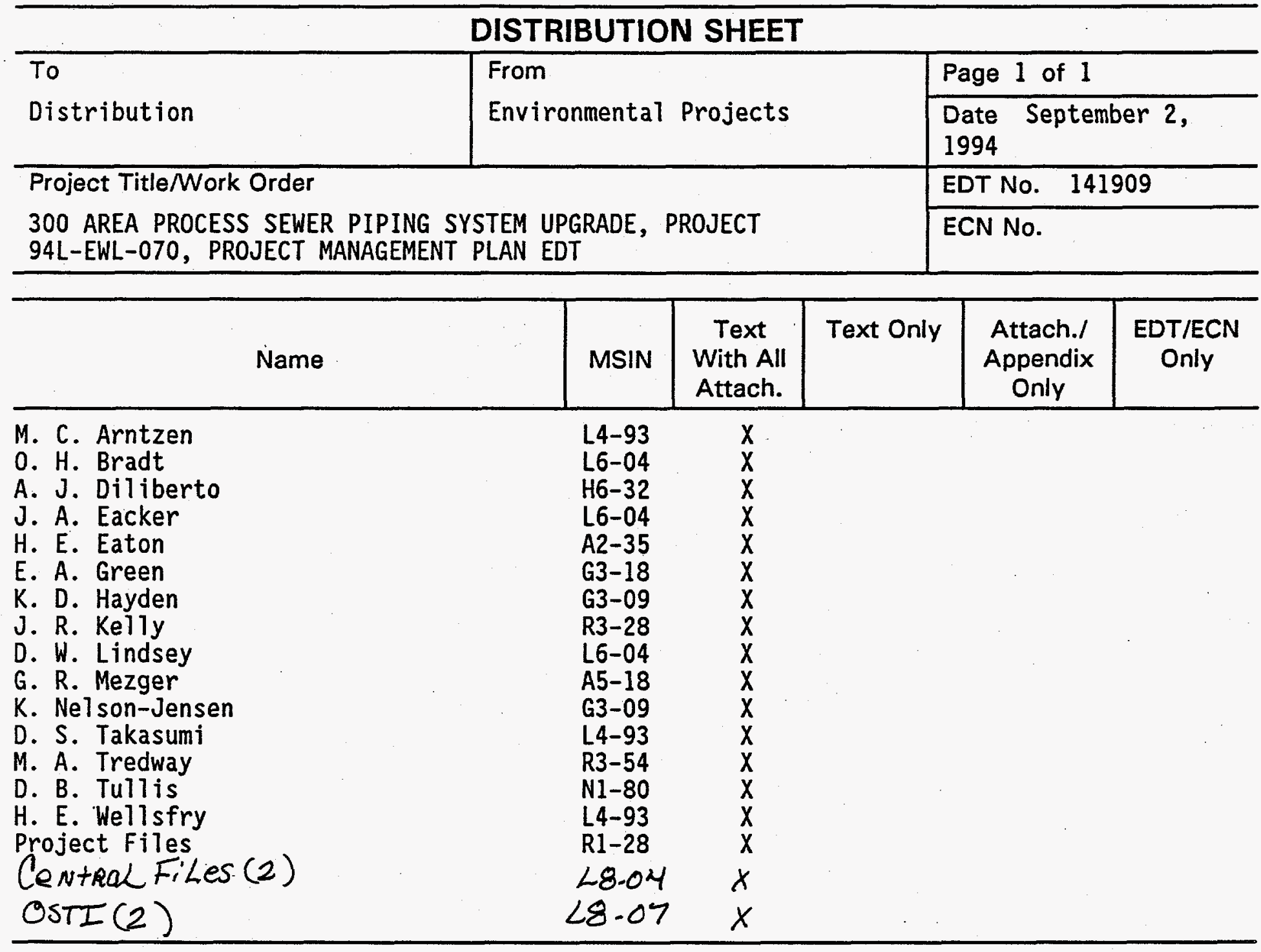




\section{DISCLAIMER}

\section{Portions of this document may be illegible in electronic image products. Images are produced from the best available original document.}




2. To: (Receiving Organization)
Engineering Document Control
8D730

5. Proj./Prog./Dept./Div.:

$\mathrm{L}-070$

8. Originator Remarks:

ORIGINAL RELEASE OF DOCUMENT

11. Receiver Remarks:
3. From: (Originating Organization) H. E. Wellsfry, Evironmental Projects, L4-93, 372-0812

\section{Cog. Engr.:}

H. E. Wellsfry
4. Related EDT NO.:

N/A

7. Purchase Order No.:

$N / A$

9. Equip./Component No.:

$N / A$

10. System/Bldg./Facility: 300

12. Major Assm. Dwg. No.: $N / A$

13. Permit/Permit Application No.: N/A

14. Required Response Date: $N / A$

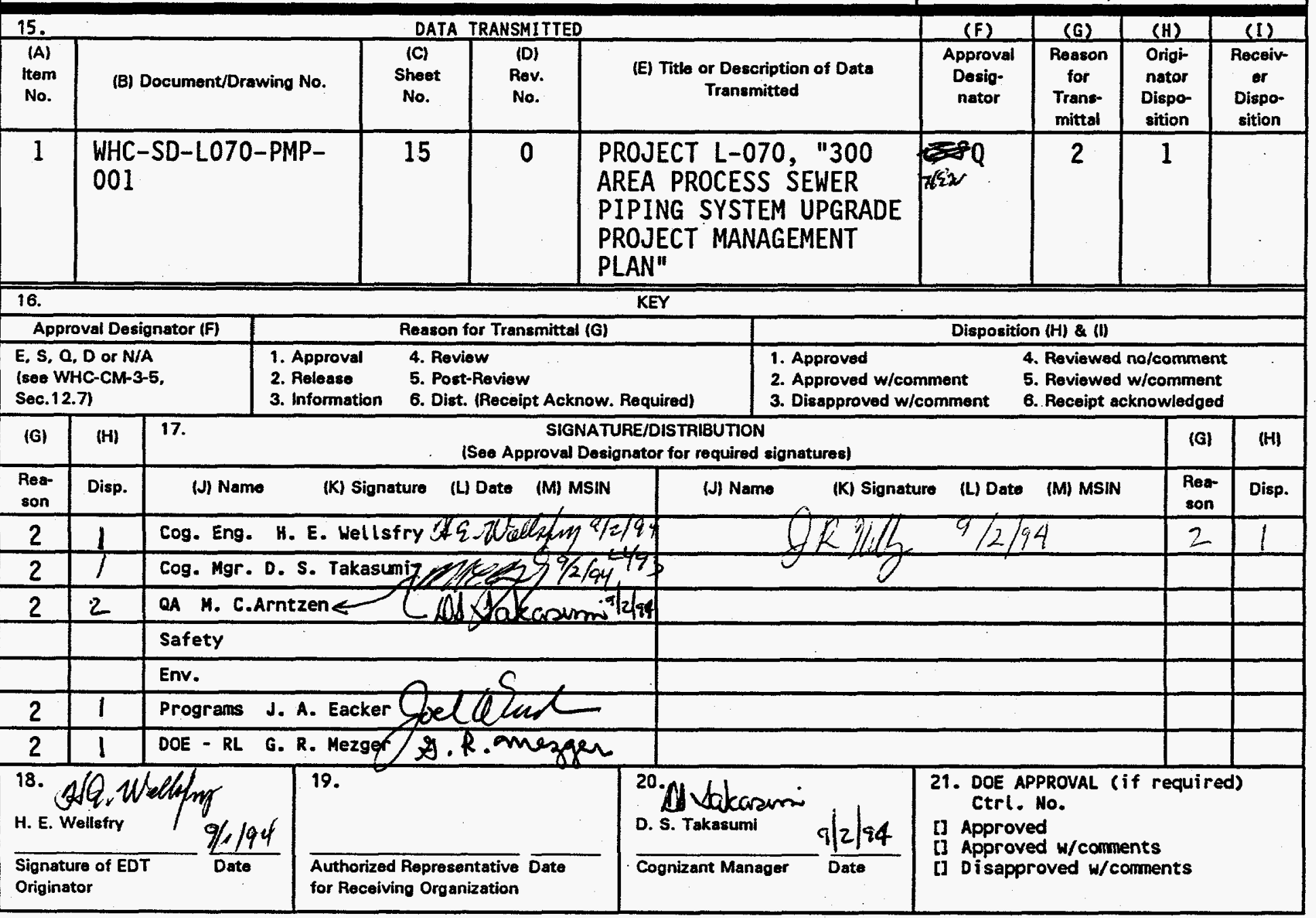

BD-7400-172-2 (04/94) GEF097 


\section{RELEASE AUTHORIZATION}

Document Number: WHC-SD-L070-PMP-001, REV. 0

Document Title: $\quad$ Project L-070 300 Area Process Sewer Piping Upgrade

Release Date: $\quad 9 / 15 / 94$

This document was reviewed following the procedures described in WHC-CM-3-4 and is:

APPROVED FOR PUBLIC RELEASE

****************

WHC Information Release Administration Specialist:

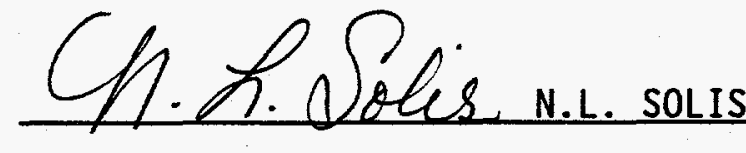

(Signature)

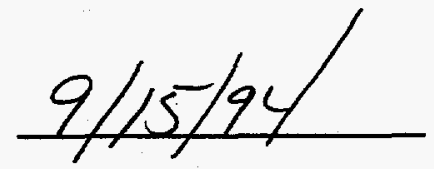

(Date) 


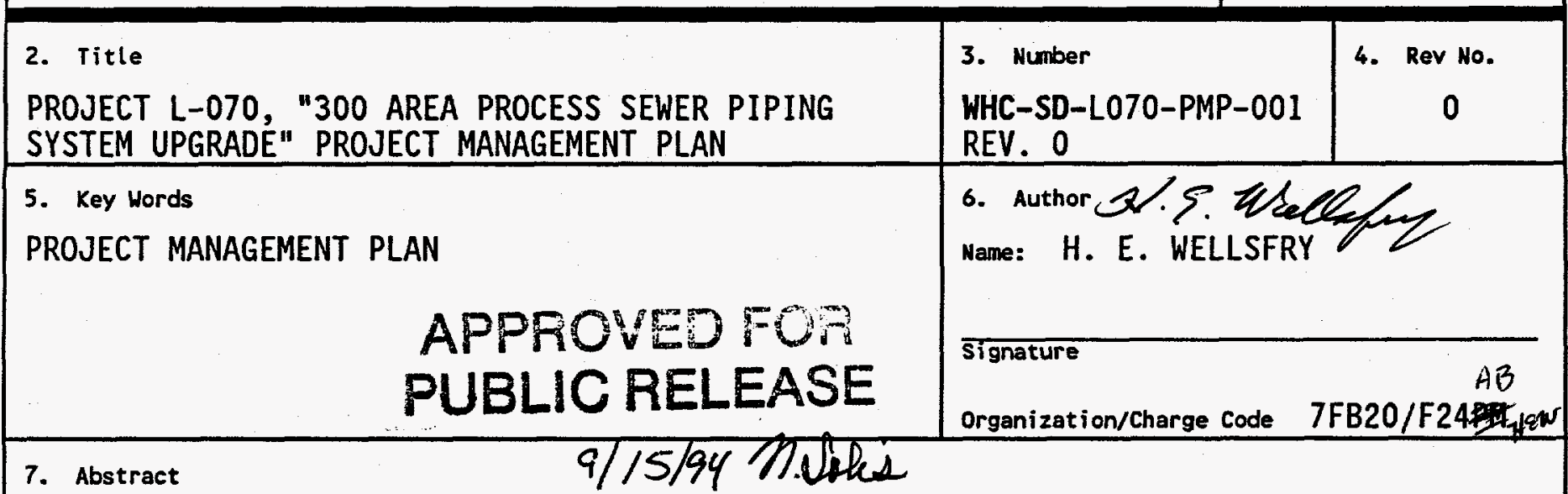

This document is the Project Management Plan for Project L-070, 300 Area Process Sewer System Upgrades.

8. PURPOS AND USE OF DOCUNEUT - This doeiment was prepar $f$ for use within the U.S. Departme of Energy and ts contractor. It is to be used only to p form, direct, or integrate work under U.S. Depar ment of E rgy contracts. This ceument is not approved for public tease itil reviewed.

PATENT STATUS This document copy, since $i$ is transmitted in advance of par in clearance, is made available it confidence solely for use $i$ pelformance of work under con acts with the U.S. Depar inent of tiergy. This document i not to published nor its contry otherwi de disseminated or us $d$ for purp es other than specifj above befort patent approval or such relea, or use has been cured, upon requit, from the Pa ent Counsel, U.S. Department of E ergy field office, hichland, WA.

DISCLAIMER - This report was prepared as an account of work sponsored by an agency of the United States Government. Neither the United States Goverment nor any agency thereof, nor any of their employees, nor any of their contractors, subcontractors or their employees, makes any warranty, express or implied, or assumes any legal liability or responsibility for the accuracy, completeness, or any third party's use or the results of such use of any information. apparatus, product, or process disclosed, or represents that its use would not infringe privately owned rights. Reference herein to any specific commercial product, process, or service by trade name, trademark, manufacturer, or otherwise, does not necessarily constitute or imply its endorsement, recomendation, or favoring by the United States Government or any agency thereof or its contractors or subcontractors. The views and opinions of authors expressed herein do not necessarily state or reflect those of the United States Government or any agency thereof.

9. Impact Level ${ }^{2 / w}-0$

10.

RELEASE STAMP

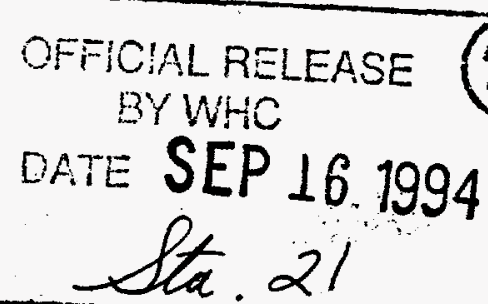




\title{
PROJECT MANAGEMENT PLAN
}

PROJECT L-070

\section{AREA PROCESS SEWER PIPING UPGRADE}

\author{
Prepared by \\ Westinghouse Hanford Company \\ February 24, 1994 \\ U.S. Department of Energy \\ Field Office, Richland \\ Richland, Washington
}

APPROVALS

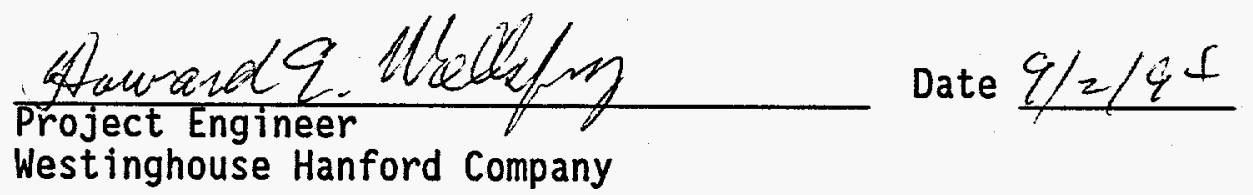

II. R. Muzger

Date $9 / 7 / 94$

Project Management Division

U.S. Department of Energy

Field Office, Richland 
TABLE OF CONTENTS

ACRONYMS

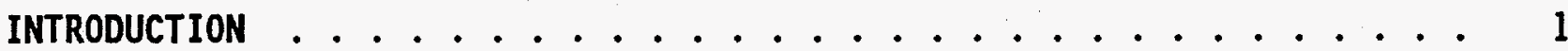

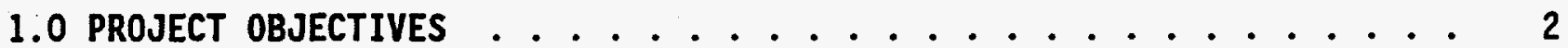

1.1 Purpose of Project ............... 2

1.2 Technical objectives ............... 2

1.3 Schedule objectives.............. 2

1.4 Cost objectives............... 2

2.0 PROJECT DESCRIPTION ................ 3

3.0 MANAGEMENT ORGANIZATION AND RESPONSIBILITY ........... 3

3.1 U.S. DEPARTMENT OF ENERGY-RICHLAND FIELD OFFICE (RL) $: 4$

3.1.1 Project Manager ............. 4

3.2 Management Team ............. 4

3.2.1 Project Integrator (PI) . . . . . . . . 5

3.2 .2 Project Integration .......... 5

3.2 .3 Program Integration .......... 5

3.2.3.1 Functional Criteria ........ 6

3.2.3.2 Project Support .......... 6

3.2.3.3 Permitting Interface ........ 7

3.2 .4 Operations ............. 7

3.2.5 Sponsoring Program ............ . 7

3.3 Engineering .............. 8

3.3.1 Construction ............. 8

3.3.1.1 Construction Forces (CF) ..... 10

3.4 Fixed Price Construction Contractors (FPCC) ..... 10

4.0 WORK BREAK DOWN STRUCTURE ............... 10

4.1 Work Breakdown ................ 10

5.0 SCHEDULE $\ldots \ldots \ldots$

5.1 Project Schedule .............. 10

6.0 PROJECT EXECUTION . . . . . . . . . . . . . . 11

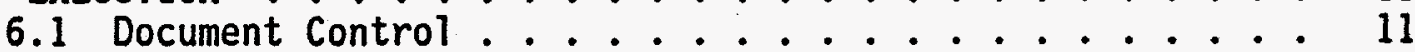

6.1.1 Safety Anatysis ............ 11

6.1.2 Submittal Control ............ 11

6.2 Design and Construction Configuration Control ..... 11

6.2.1 Baseline Management .......... 11

6.2.2 Project Engineer Responsibilities ...... 12

6.2.3 Project Manager Responsibilities ........ 12

6.2.4 Engineer/Constructor .......... 12

6.3 Quality Assurance ................ 12

6.3.1 Quality Assurance Program Plan ......... 12

6.3.2 Quality Assurance Records ........... 12

6.3 .3 Audits ............... 13 
6.4 Monthly Reports .............. 13 6.4.1 Project Meetings ............ 13

7.0 PROJECT CONTROL . . . . . . . . . . . . . . 13

7.1 Technical Baseline ............ 13

7.2 Schedule Baseline . . . . . . . . . . 14

7.3 Cost Baseline ............... 14

7.4 Change Control Requirements .......... 14

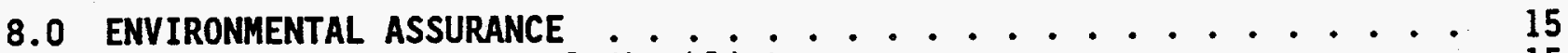

8.1 Environmental check 1 ist $\ldots \ldots$

9.0 PROCUREMENT PLAN . . . . . . . . . . . . . 16

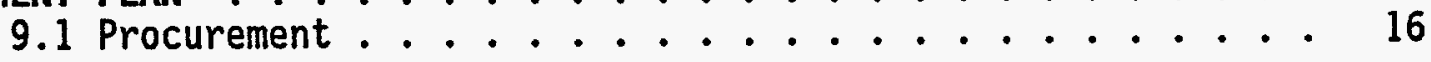

10.0 REFERENCES . . . . . . . . . . . . . 17

ATTACHMENT A . . . . . . . . . . . . 18

PROJECT MASTER SCHEDULE $\ldots \ldots \ldots \ldots$

ATTACHMENT B ............................. 19

BUDGET AUTHORIZATION/BUDGET OBLIGATION ........... 19

ATTACHMENT C ............................ 20

SUMMARY ESTIMATE ....................... 20

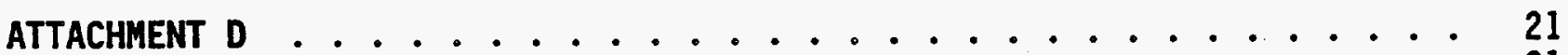

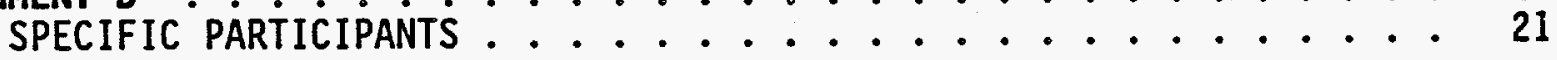

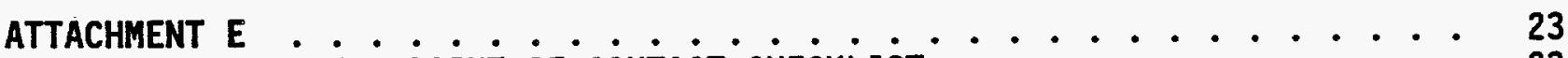

ENVIRONMENTAL POINT OF CONTACT CHECKLIST $\cdots \cdots \cdots$ 
WHC-SD-L070-PMP-001, Rev. 0

\section{ACRONYMS}

$\begin{array}{ll}\text { AI } & \text { Acceptance Inspection } \\ \text { ATP } & \text { Acceptance Test Procedure } \\ \text { ANSI } & \text { American National Standards Institute } \\ \text { ASME } & \text { American Society of Mechanical Engineers } \\ \text { BA/BO } & \text { Budget Authority/Budget Outlay } \\ \text { CCB } & \text { Change Control Board } \\ \text { CDR } & \text { Conceptual Design Report } \\ \text { CF } & \text { Construction Forces } \\ \text { CM } & \text { Construction Management } \\ \text { CR } & \text { Change Request } \\ \text { D/C } & \text { Design Construct } \\ \text { DOE } & \text { U.S. Department of Energy } \\ \text { DOE-HQ } & \text { U.S. Department of Energy-Headquarters } \\ \text { RL } & \text { U.S. Department of Energy-Richland Operations Office } \\ \text { EA } & \text { Environmental Assessment } \\ \text { EAC } & \text { Estimate At Completion } \\ \text { EPA } & \text { U.S. Environmental Protection Agency } \\ \text { ETF } & \text { Effiuent Treatment Facility } \\ \text { FDC } & \text { Functional Design Criteria } \\ \text { FCC } & \text { Fixed Price Construction Contractor } \\ \text { FSAR } & \text { Final Safety Analysis Report } \\ \text { FY } & \text { Fiscal Year } \\ \text { IMT } & \text { Integrated Management Team } \\ \text { KEH } & \text { Kaiser Engineers Hanford Company } \\ \text { LOI } & \text { Letters of Instruction } \\ \text { NEPA } & \text { National Environmental Protection Act } \\ \text { OTP } & \text { Operational Test Procedure } \\ \text { PA } & \text { Project Authorization } \\ \text { PI } & \text { Project Integrator } \\ \text { PM } & \text { Project Manager } \\ \text { PMD } & \text { Project Management Division } \\ \text { PMP } & \text { Project Management Plan } \\ \text { PNL } & \text { Pacific Northwest Laboratories } \\ \text { PSAR } & \text { Prel iminary Safety Analysis Report } \\ \text { PSWBS } & \text { Project Summary Work Breakdown Structure } \\ \text { QA } & \text { Quality Assurance } \\ \text { QAPP } & \text { Quality Assurance Project Plan } \\ \text { SD } & \text { Supporting Document } \\ \text { SDRD } & \text { Supplemental Design Requirements Document } \\ \text { SURR } & \text { Start-Up Readiness Review } \\ \text { TEC } & \text { Total Estimated Cost } \\ \text { TEDF } & \text { Treated Effluent Disposal Facility } \\ \text { WBS } & \text { Work Breakdown Structure } \\ \text { WHC } & \text { Westinghouse Hanford Company } \\ & \end{array}$


WHC-SD-L070-PMP-001, Rev. 0

\section{PROJECT MANAGEMENT PLAN}

\section{INTRODUCTION}

This Project Management Plan (PMP) reflects the recommendation of the Defense Nuclear Safety Board (DNSB) to empower the U.S. Department of Energy (DOE) Operating Contractor with complete authority to complete assigned tasks. The result of this recommendation is a change in the historic role of the Onsite Engineer Contractor Kaiser Engineer Hanford (KEH) as being duly assigned to the Onsite Operating Contractor Westinghouse Hanford Company (WHC) effective January 1, 1994. The $\mathrm{plan}$ describes such roles, changes and responsibilities of the project team which includes the U.S. Department of Energy Operations Office, Richland (RL), Westinghouse Hanford Company (WHC), and others as appropriate.

This PMP satisfies U.S. Department of Energy (DOE) Order 4700.1 which sets forth policies and requirements to be followed in the management of all RL projects. Use of this document is described in the Project Management Manual, WHC-CM-6-2, and the Projects Department Procedures, WHC-CM-6-12. 
WHC-SD-L070-PMP-001, Rev. 0

\subsection{PROJECT OBJECTIVES}

\subsection{Purpose of Project}

Project $L-070,300$ Area Process Sewer Piping Upgrade will replace the existing aged and deteriorating gravity process sewer pipe system in the 300 area with a liquid effluent collection system composed of gravity, pressure and/or vacuum where appropriate.

\subsection{Technical objectives}

The Technical objectives for the project are identified in the Functional Design Criteria WHC-SD-L070-FDC-001, Revision 1, or subsequent revisions as approved by RL.

\subsection{Schedule Objectives}

The project schedule baseline is reflected below. The project master schedule, Attachment A, illustrates schedule completion objectives.

\begin{tabular}{lll}
\multicolumn{1}{c}{ ACTIVITY } & START & COMPLETE \\
\cline { 2 - 3 } Engineering & $01 / 94$ & $01 / 95$ \\
Field Engineering & $02 / 95$ & $12 / 96$ \\
Onsite Construction & $02 / 95$ & $10 / 96$ \\
Fixed Price Procurement & $01 / 95$ & $05 / 95$ \\
Fixed Price Construction & $06 / 95$ & $10 / 96$ \\
Project Integration & $01 / 94$ & $12 / 96$ \\
Other Project Support & $01 / 94$ & $12 / 96$
\end{tabular}

If a TPA CR is required the following are deadline submittal dates: M-17-06J submit design Aprif 30, 1995 is January 15, 1995 and M-17-06K replace process sewer June 30, 1997 is March 18, 1997.

\subsection{Cost Objectives}

The overall capital cost for the project is approximately $\$ 11.7 \mathrm{M}$ dollars, based upon the summary cost (Attachment $C$ ) estimate in the Advance Conceptual Design Report ACDR-SD-L070-CDR-001, Rev. 0.

\begin{tabular}{llrl} 
WBS & ELEMENT & CACTIVITY & CAPITAL(SK) EXPENSE (SK) \\
\hline 1.0 & Engineering & 390 & \\
1.2 & Field Engineering & 340 & \\
3.0 & Construction & 5,530 & \\
3.3 & O.C. Construction (Burial) & 920 & \\
4.0 & Project Integration & 620 & \\
5.0 & Other Project Support & & 1,800 \\
& Contingency & $\frac{1,500}{9,900}$ & $\overline{11,700}$
\end{tabular}

The budget BA/BO schedule, Attachment B shows the capital budget requirements for the project. Future revisions to the $B A / B O$ schedule will be documented by an approved change request. 
WHC-SD-L070-PMP-001, Rev. 0

\subsection{PROJECT DESCRIPTION}

The existing 300 Area process sewer system piping consists of approximately 34,500 liner feet of piping ranging from 4 inches to 36 inches, with discharges from some 60 buildings and/or facilities. Discharge practices of the past 47 years of service are known to consist of quantities of uranium, acid, solvents, organic, and other chemicals used in operation of the 300 Area.

The vitrified clay piping system integrity is questionable due to the build up of deposits over its life of service, and known cracks in the piping system. This creates the concern from the limited information achieved from pipe video taping of possible exfiltration.

The piping $(29,200$ liner feet) system will require several pressure lift stations for the high flow discharges, vacuum valve stations for low flow scenarios and gravity flow as the first alternative when prudent. The system will collect the process sewer at a central and satellite station for pressure transport to the L-045H Treated Effluent Disposal Facility (TEDF) sump.

The pressure lift stations when utilized will consist of two submersible pumps installed in a concrete wet pit. Pumps will be duplex, complete with standby power, electrical switch gear, and a monitoring network with connection to a central collection station. The vacuum system will have monitoring capabilities of the vacuum pump and vacuum reservoir tank associated with the central collection station.

The new piping system is proposed to address the issue of pipe deterioration, and possible exfiltration into the soil column. The new process sewer system will discharge the liquid effluent to the Treated Effluent Disposal Facility collection sump located in the northeast corner of the 300 Area for subsequent pumping to the treatment facility. The Project $L-070$ will provide the proposed piping support to Project $L-045 \mathrm{H}, 300$ Area Treated Effluent Disposal Facility, and will preclude possible exfiltration into the soil column.

\subsection{MANAGEMENT ORGANIZATION AND RESPONSIBILITY}

This section identifies the major project specific participants (Attachment D) and establishes the organizational authority, responsibility, and accountability required to effectively manage this project. This section also specifies the authority, responsibility, and accountability for management of the project baseline (scope, cost, and schedule); quality assurance (QA); regulatory requirements (health, safety, and environmental protection); and interface management and control. 
WHC-SD-L070-PMP-001, Rev. 0

\subsection{U.S. DEPARTMENT OF ENERGY-RICHLAND FIELD OFFICE (RL) \\ Office of Assistant Manager for Environmental (AME) Management}

The AME has assigned a RL Project Manager (PM) to provide technical surveillance, overview and evaluation of project execution to assure compliance with the project authorization, design criteria, and RL requirements.

\subsubsection{Project Manager}

The RL PM will provide overview management that project activities are planned, managed, and reported in compliance with DOE orders, regulatory requirements, and baseline documents. The RL PM will also provide overview management of design and construction activities of the operating contractor. The RL PM will finally provide management oversight for the budgetary and technical aspects of the project.

\subsection{Management Team}

\section{WESTINGHOUSE HANFORD COMPANY}

The project management team role and responsibility for the design, procurement, and construction of this project is defined below. The approach streamlines project management by focusing team members at the project level with a common objective. The project includes all activities, expense and capital, required to successfully complete the project.

The following performing organizations are the major project participants:

* Project Integrator (PI)

* Project Integration Group

* Program Integration

* Operations

* Sponsoring Program

* Engineering

Definitive Design and

Engineering During

Construction
Westinghouse Hanford Company

Westinghouse Hanford Company

Westinghouse Hanford Company

Westinghouse Hanford Company

Kaiser Engineers Hanford Company

Westinghouse Hanford Company (assigned to Kaiser Engineers Hanford Company) 
WHC-SD-L070-PMP-001, Rev. 0

Construction

Perform Onsite Construction

Manage Fixed-Price Contractor

Acceptance Inspection

Westinghouse Hanford Company

(assigned to Kaiser Engineers

Hanford)

* Quality Assurance

Performance Assessment

Westinghouse Hanford Company

\subsubsection{Project Integrator (PI)}

WESTINGHOUSE HANFORD COMPANY

The PI has overall responsibility for project implementation and is the ultimate decision making authority within the management team.

The PI is accountable to the Westinghouse Management for project cost, schedule, scope, and technical performance of the L-070 Project. The PI will be responsible for performing the overview of all project activities to ensure that quality work is safe, environmentally sound, and cost effective. Specific responsibilities are assigned to the performing organizations by the PI.

\section{Summary of Responsibilities}

- Overall responsibility for project implementation

- Responsible for Project Management Plan

- Responsible for technical performance, safety, acceptance testing, and closing-out project

- Central point-of-contact with Kaiser Engineer Hanford assigned to Westinghouse Hanford Company

- Provides final technical oversight for definitive design, and construction services

- Approves official completion of design, and construction

\subsubsection{Project Integration WESTINGHOUSE HANFORD COMPANY}

Because of the size and complexity of this project, the PI will be supported by the project specific participants provided in Attachment D.

\subsubsection{Program Integration \\ WESTINGHOUSE HANFORD COMPANY}

The WHC Liquid Effluent Treatment Program will provide program integration for the project. 
WHC-SD-L070-PMP-001, Rev. 0

\section{Summary of Responsibilities}

- Responsible for FDC

- Coordinate permitting and submit to regulators

- Interface with the RL Program personnel concerning the project activities

- Define overall requirements of the process sewer piping system

- Define the building administrative controls on discharges points

- Project support

- Technical support

\subsubsection{Functional Criteria}

It is the responsibility of the sponsoring program to provide the Functional Design Criteria (FDC) for the project. The approved FDC for this project is WHC-SD-LO70-FDC-001, Rev. 1. The maintenance of this document and subsequent revisions are the responsibility of the WHC Program representative. Any revisions, deviations, or variations to the project FDC must comply with the established Change Control requirements described in Section 7.4.

\subsubsection{Project Support}

The Liquid Effluent Treatment Program will manage the expense funding for project support. The Project Support activities are summarized as follows:

- Provide Technical Support in design reviews

- Perform engineering analysis as required

- Perform safety analysis as required

- Define operational requirement in meeting permit requirements.

Further technical support for activities such as design review, submittal reviews, and building discharge administrative controls implementation will be provided. 
WHC-SD-L070-PMP-001, Rev. 0

\subsubsection{Permitting Interface}

The Liquid Effluent Treatment Program Manager will provide the required interface with the permitting organizations and the regulatory agencies. This interface will be executed with the direct involvement of the PI and these activities will be evaluated against the project baselines and critical path.

\subsubsection{Operations}

WESTINGHOUSE HANFORD COMPANY

The end user of Project L-070 will be the 300 Area Liquid Effluent Facilities organization within WHC. Project support from the operations organization is essential to assure that the operational objectives of the facility are achieved. Support for design reviews, submittal reviews, procedure development, readiness review and operator training are the primary responsibilities of this organization. Interface with the project team and contractors during construction is essential to develop competent and efficient operating personnel.

The Operations organization is responsible for the operations/maintenance interface, operational testing, official acceptance of completed construction for the operating contractor, readiness review, and training.

\section{Summary of Responsibilities}

- Provides Operational/Maintenance interface

- Prepare Operational Test Procedures (OTP), conduct OTP and startup readiness review

- Performs operational acceptance testing, readiness review, and training

- Develops operations and maintenance procedures

\subsubsection{Sponsoring Program}

KAISER ENGINEERS HANFORD COMPANY

KEH Landlord Program Management is the sponsoring program and has responsibility for the following:

1. Providing project funding

2. Including project activities in work plans

3. Maintaining technical oversight responsibility

4. Providing reporting to DOE programs 
WHC-SD-L070-PMP-001, Rev. 0

Summary of Responsibilities

- Project funding includes both capital and expense funding for all project activities. These fund plans are included in Cost Account Authorizations and Cost Account Plans administered and controlled by LPM.

- Project activities will be included in the LPM FY Work PI an and 5-Year Plan.

- Initial documents and changes to established budgets, schedules, milestones, and technical requirements are also monitored and approved by LPM to ensure program objectives are being met. Change control

class/level 0 , I, and II are approved by LPM.

- LPM will maintain and provide reporting to DOE program counterparts.

\subsection{Engineering}

WHC (ASSIGNED TO KEH)

Engineering services will be provided by WHC who assigned this task to KEH. WHC will manage engineering activities. The engineering organization is responsible to the PI for cost, schedule, technical compliance, of the design aspects. RL will overview the technical activities. The following services will be provided:

- Provide the design media with the support of a specialty civil engineering firm for the process sewer piping system. This shall include acceptance tests, training and start-up support, start-up procedures, operations manuals, vendor information, maintenance manuals, and an Energy Conservation Report.

- Provide the construction fair cost estimate at the end of design.

\subsubsection{Construction}

WHC (ASSIGNED TO KEH)

The Construction Management organization will provide assigned construction services, including inspection and construction supervision, with the support of a specialty civil engineering firm to construct the project through a fixed price contract.

The Construction Management (CM) organization is responsible to the PI for cost, schedule, and technical compliance to the requirements of this project. It is the policy and intent to perform the construction activities with fixed price contractors whenever possible. The $\mathrm{CM}$ is responsible for management of fixed price construction contracts. On-site construction by KEH Construction Forces (CF) is managed as an integral part of the overall construction program for Project L-070. Site safety and environmental compliance for construction activities is the responsibility of the construction organization and is managed as part of these programs. 
WHC-SD-L070-PMP-001, Rev. 0

Inspection services are provided through Acceptance Inspection (AI) to provide construction approval to approved inspection $\mathrm{plans,} \mathrm{structured}$ inspection programs, and audits and surveillances.

Acceptance Inspection for the Government is performed by KEH AI for the project, procurement, and construction activities. The AI will assure conformance to the technical requirements through a planned inspection program based on overview inspections of the work being performed by the various vendor's, and contractors. Each primary vendor and contractor will perform inspection of their own work.

These inspections are intended to provide assurance that the design requirements are properly incorporated into the work and that these inspections are performed on a timely basis. All inspections will conform to a $\mathrm{plan}$ developed and approved during detailed design and to the requirements set forth in the project Quality Assurance Program Plan (QAPP) section 6.3.

The AI will perform inspections of critical components and characteristics. The components requiring verification will be determined during their detailed design. In addition, the AI will overview selected vendor/contractor inspections to assure conformance to the overall inspection program. The AI retains the organizational independence to act as the Government's inspection agency through KEH. This program adheres to the applicable requirements of NQA-1 and DOE orders.

\section{Summary of Responsibilities}

- Contract administration

- Construction safety

- Perform construction management

- Provide for fixed price construction contractors and construction forces

- Coordinate overall construction

- Responsible for the following:

- Bid package preparation and award of the fixed price construction

- Field Engineering

- Site Safety

- Constructibility review

- Start-up support

- Records Management acceptance

- Testing and turnover

- Submittal control 
WHC-SD-L070-PMP-001, Rev. 0

- Punch list

- Close out project documents

\subsubsection{Construction Forces (CF)}

The CF will be responsible to the construction manager of final tie-ins to the 300 Area Facility buildings. The CF will perform selected construction activities related to work in potentially contaminated areas. The CF will be responsible to Construction for cost, schedule, and technical compliance for their scope of work. The CF will comply with all applicable safety and environmental programs through compliance to existing WHC programs.

\subsection{Fixed Price Construction Contractors (FPCC)}

The FPCC is responsible for procurement, construction, acceptance testing, and start-up support for the continuous discharge of the process sewer system piping upgrade. The contractor will be selected through the competitive bid process. The FPCC will be accountable to WHC (assigned through the Construction Management Organization) for the cost, schedule, and technical compliance of their scope of work. The FPCC will also be accountable to perform their activities in accordance with approved safety and environmental programs which fall within the overall site programs. Acceptance testing, as required, will be performed to assure functional requirements are achieved.

\subsection{WORK BREAK DOWN STRUCTURE}

\subsection{Work Breakdown}
1.0 Engineering
1.2 Field Engineering
3.0 Construction
4.0 Project Integration
5.0 Other Project Support

\subsection{SCHEDULE}

\subsection{Project Schedule}

There are two Tri Party Agreement Milestone associated with the project. The TPA Milestones are M-17-06J, Submit Design Documentation for the 300 Area Process Sewer Piping Replacement to EPA, and Ecology by April 1995, and M-17-06K Replace the 300 Area Process Sewer Piping beginning at five feet from outside the contributor buildings, and replace the piping up to the interface point to the 300 Area Treated Effiuent Disposal Facility by June 1997. The Milestones are referenced in the master schedule in section 1.3. 
WHC-SD-L070-PMP-001, Rev. 0

\subsection{PROJECT EXECUTION}

\subsection{Document Control}

The existing document control station will be utilized to support the project requirements. Documents will be externally released and accessible to the project team when appropriate. Associated correspondence with the project will be controlled by this document control station.

\subsubsection{Safety Analysis}

The project Functional Design Criteria (WHC-SD-L070-FDC-001, Rev. 1) does not require a safety analysis based upon the analyzed bounds of an applicable Safety Analysis Report (SAR).

\subsubsection{Submittal Control}

The engineering responsibilities for this project include submittal processing and control. Project specific procedures will be prepared that identify the requirements for processing submittals.

\subsection{Design and Construction Configuration Control}

WHC shall be responsible to assure that the assigned engineering organization maintains a design QA PIan to control design, and those changes to the design that arise during construction, in accordance with the change control process described in Section 7.4.

KEH shall be responsible to assure that the various construction contractors establish construction Quality Control to control construction in accordance with applicable requirements.

The construction contractor(s) are responsible for establishing, implementing, and documenting an inspection program in accordance with approved specifications and drawings.

\subsubsection{Basel ine Management}

The scope, schedule, and cost baseline management for all aspects of this project are evaluated and monitored by the Project Integration organization. Revisions and/or changes required to any of these baseline elements must be initially approved by the PI. The formal revisions to these elements are executed as part of the Change Control Process defined in Section 7.4. 
WHC-SD-L070-PMP-001, Rev. 0

\subsubsection{Project Engineer Responsibilities}

The WHC project engineer is responsible for determination of class change, assigning cause codes, evaluation and preparation of the change request, and approving the Class I and II changes prepared by the engineer/constructor. The project engineer will also assist the user representative in reviewing and approving changes to ensure compatibility with sponsor objectives.

\subsubsection{Project Manager Responsibilities}

The WHC project manager is responsible for approving $\mathrm{Class} \mathrm{I}$ and II changes, and scheduling change control meetings for approval. A Level 3 Manager is required to approve all Class I change requests.

\subsubsection{Engineer/Constructor}

When the engineer/constructor prepares the project change request, the preparer is responsible for providing technical supporting documentation and assist in reviewers in evaluating cost, schedule, and technical impacts of the change.

\subsection{Quality Assurance}

The overall $Q A$, including quality engineering for the project will be planned and implemented in accordance with DOE Order 5700.6C, RL 5700.1A, ASME NQA-1 (latest edition) and other applicable quality standards. Quality activities will be graded based on the potential impact on environmental, safety, and health and reliability and continuity of operations.

\subsubsection{Quality Assurance Program Plan}

All project related activities shall establish and implement appropriate quality assurance requirements identified in the Project Quality Assurance Plan (QAPP). The QAPP for this project is WHC-SD-L070-QAPP-001, Rev. 0. Conditions adverse to quality are identified in nonconformance reports, audit reports, surveillance reports, and corrective action requests. Investigation and corrective actions in response to these adverse conditions shall be completed in a timely manner.

\subsubsection{Quality Assurance Records}

Each organization that maintains QA records will be required to control them in accordance with the applicable requirements of NQA-1. 
WHC-SD-L070-PMP-001, Rev. 0

\subsubsection{Audits}

Internal and external audits are to be performed by the quality Compliance Assurance Organization to assure project compliance with QA program requirements. These will be performed in accordance with the Quality Assurance Project Plan QAPP in section 6.3.1.

\subsection{Monthly Reports}

An integrated monthly report will be submitted by the PI to RL and will contain information in the areas listed below.

- Major accomplishments

- Issues and Corrective actions

- Cost performance

- Schedule status

The information contained in these reports will be obtained from the same data base that supports day-to-day management by the project participants.

\subsubsection{Project Meetings}

The PI has lead responsibility to conduct biweekly status reviews which are conducted with all project participants responsible for providing support to Project L-070. The meetings will focus on cost status, schedule status, and problem areas or potential problem areas. The meeting will cover:

(1) significant progress and work status, (2) significant problems and planned solutions, (3) contingency status and (4) cost and schedule status.

Subsequent meetings will highlight previously identified problems and their current status, as well as disposition of previously identified priority efforts.

The project will be reported on in depth to RL by the PI at the regularly scheduled monthly Management Review Meeting.

\subsection{PROJECT CONTROL}

\subsection{Technical Basel ine}

This project's technical baseline is defined by the project's FDC, WHC-SD-FDC-L070-001, Rev 1. The FDC may be further expanded as appropriate by a separate Supplemental Design Requirements Document (SDRD) or by letters of instruction (LOI) to further define specific design requirements. Changes to the FDC require Project Change Control approval as defined in Section 4.3. 
WHC-SD-L070-PMP-001, Rev. 0

\subsection{Schedule Baseline}

The baseline schedule objectives are outlined in 1.3 .

\subsection{Cost Baseline}

The Project Authorization (PA) authorizes funding for the project. The PA requires that work be performed consistent with the scope, cost estimate, and schedule baselines. Changes to baselines as a result of revised planning for a fiscal year will require a modification to the PA. A PA modification will be prepared each year as additional budget authority is made available.

The total estimated cost (TEC) for the project is approved and controlled by DOE-HQ. The TEC is initially established with the conceptual design and becomes baseline after formal validation by DOE-HQ. The funding baseline for the project is the approved $B A / B O$ schedule. The funding baseline represents the amount and timing of funding required to complete the project within the scope, cost, and schedule baselines. The TEC for Project L-070

is $\$ 9.9 \mathrm{M}$ dollars.

\subsection{Change Control Requirements}

Change Control action is initiated to address changes to the project scope, schedule or cost that exceed the thresholds defined in this section. All changes are approved and documented using the Change Request form (CR). Change Requests shall be completed immediately upon the identification of a prospective change as described in Section PM-14 of WHC-CM-6-2, Projects Department Procedures. If a CR is prepared, based on preliminary information the final impact assessment information will be compared to identify any significant difference. If the difference is significant, the original CR will be referenced in a follow-up CR. A significant difference is defined as one that differs from the preliminary information by $10 \%$ or more. Three types of change classifications have been identified for control of baseline. changes. The classes, and the approval authority that will administer them, are shown in the following table:

\section{CLASS/LEVELS}

0 .

I.

\section{CHANGE CONTROL THRESHOLDS}

1. All changes impacting Level 0 scope

2. Schedule extensions in excess of six months

3 . Cost changes in excess of $\$ 10$ mitrion

1. All changes impacting Level 1 scope

2. Schedule extensions in excess of four months or more when TPA milestones cannot be achieved

3. Cost changes in excess of $\$ 5$ million of the TEC

4. Any increase to the TEC or TPC 
WHC-SD-L070-PMP-001, Rev. 0

\section{CLASS/LEVELS}

II.

III.

\section{CLASSIFICATION}

0

I

II

III

IVa

IVb
CHANGE CONTROL THRESHOLDS

1. All changes impacting Level 2 scope or RL performance baselines

2. Any schedule change of one month or more impact

3 . Any use of contingency of $25 \mathrm{~K}$ or more

1. Changes not impacting Levels 0,1 , and 2 scope

2. Schedule milestones not classified as Levels 0,1 , and 2

3. Cost changes not classified as Levels 0,1 , and 2
$>10 \mathrm{~m} />6$ month Acquisition/Executive DOE-HQ

250K/4 month WHC submit to RL COR for approval

25K-250K/1 month WHC submit CR to RL PM for approval

$25 K / 2$ week

KEH submit CR to WHC for C.B. approval

$10 \mathrm{~K} /<1$ week

$<5 K / 1$ week
KEH submit CR for WHC PE approval

KEH Log/Trend

*Change requests will only be used to obtain changes to performance measurement baselines. Funds requests, which do not change the base lines, will be used to obtain funds to cover contractor performance problems. Al1 project change requests are 1 imited to changes in contingency. WHC shall submit to RL all other change requests for information.

\subsection{ENVIRONMENTAL ASSURANCE}

\subsection{Environmental Checklist}

The Environmental Point of Contact Checklist (Attachment E) provides potential permits and approvals for Project L-070. Preliminary review indicates that nine of the eleven permits/approval are needed to support construction activities. The remaining two permits and approvals support definitive design (one permit) and operations (one permit). 
WHC-SD-L070-PMP-001, Rev. 0

\subsection{PROCUREMENT PLAN}

\subsection{Procurement}

The current project strategy indicates that there are no long lead procurement items that must be provided to the fixed price construction contractor. Any deviations to this strategy that develop during definitive design will be defined in a procurement plan. 
WHC-SD-L070-PMP-001, Rev. 0

\subsection{REFERENCES}

ANSI/ASME NQA-1, 1989, Quality Assurance Program Requirements for Nuclear Facilities, Fairfield, New Jersey.

DOE, 1987, Order 4700.1, Project Management System, U.S. Department of Energy, Washington, D.C.

DOE, 1986, Order 5480.5, Safety of Nuclear Facilities, U.S. Department of Energy, Washington, D.C.

DOE, 1986, Order 5481.1B, Safety Analysis and Review System, U.S. Department of Energy, Washington, D.C.

DOE, 1988, Order 5500.2, Emergency Notification, Reporting and Response Levels, U.S. Department of Energy, Washington, D.C.

DOE, 1981, Order 5500.3, Reactor and Nonreactor Nuclear Facilities Emergency Planning Preparedness and Response Program for DOE Operation, U.S. Department of Energy, Washington, D.C.

DOE, 1991, Order 5700.6C, Quality Assurance, U.S. Department of Energy, Washington, D.C.

DOE, 1989, Order 6430.1A, General Design Criteria, U.S. Department of Energy, Washington, D.C.

DOE-RLIP, 1991, 4700.1A, Project Management System, U.S. Department of Energy Field Office, Richland, Richland, Washington.

DOE-RL, 1990, Order 6430.1C, Hanford P1ant Standards (HPS) Program, U.S. Department of Energy Field Office Richland, Richland, Washington.

WHC-CM-4-2, Quality Assurance Manual, Westinghouse Hanford Company, Richland, Washington.

WHC-CM-6-1, Standard Engineering Practices, Westinghouse Hanford Company, Richl and, Washington.

WHC-CM-6-2, Project Management Manual, Westinghouse Hanford Company, Richland, Washington. 
WHC-SD-L070-PMP-001, Rev. 0

ATTACHMENT A

PROJECT MASTER SCHEDULE

$A-0$ 


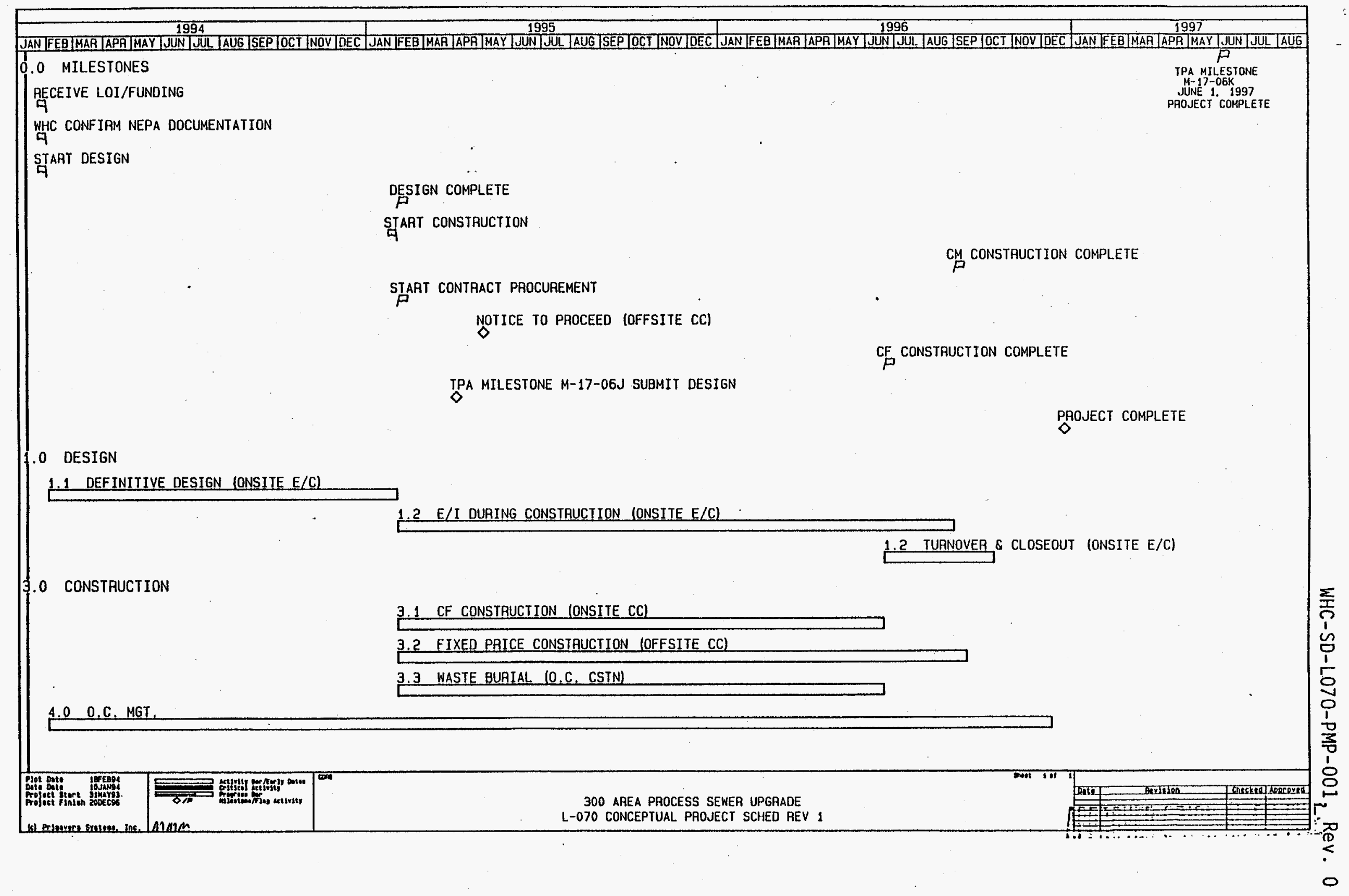


WHC-SD-L070-PMP-001, Rev. 0

\section{ATTACHMENT B}

\section{BUDGET AUTHORIZATION/BUDGET OBLIGATION}


$E N G I N E E R S$

I A NFOR D

\section{AREA PROCESS SEWER UPGRADE}

BA / BO SCHEDULE

\subsection{ENGINEERING}

1.1 DefINITIVE DESIGN

1.2 E \& I DURING CSTN.

\section{-3.0 CONSTRUCTION}

3.1 ONSITE CONST.

3.2 FIXED PRICE CONST.

3.3 O.C. CONSTRUCTION

4.0 PROJ. INTEGRATION

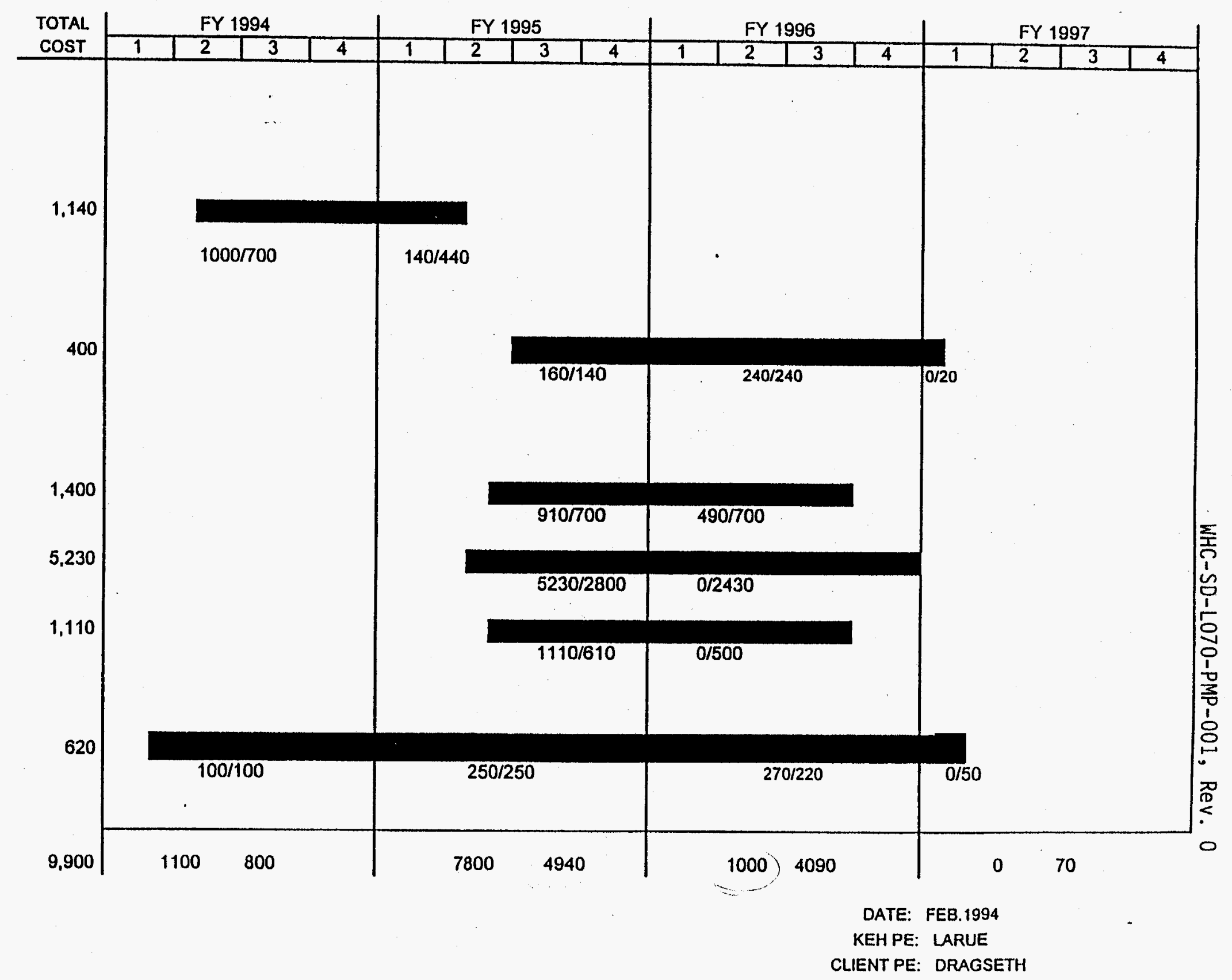


WHC-SD-L070-PMP-001, Rev. 0

ATTACHMENT C

SUMMARY ESTIMATE

CoO 
KAISER ENGINEERS IIAHFORD

WESTINGHOUSE HANFORD COMPANY

JOB HO. $1070 / E R 4561$

FILE NO. LOTOBACL
* * IEST - INIERACTIVE ESTIMATING * *

300 AREA PROCESS SEHER PIPING UPGRADE CONCEPTUAL ESTIMAIE

DOE_RO1. PROJECT COST SUMMARY
PAGE 1 OF 11

DATE $02 / 24 / 94 \quad 06: 17: 30$

BY KIR/JJM/LGU/KDE

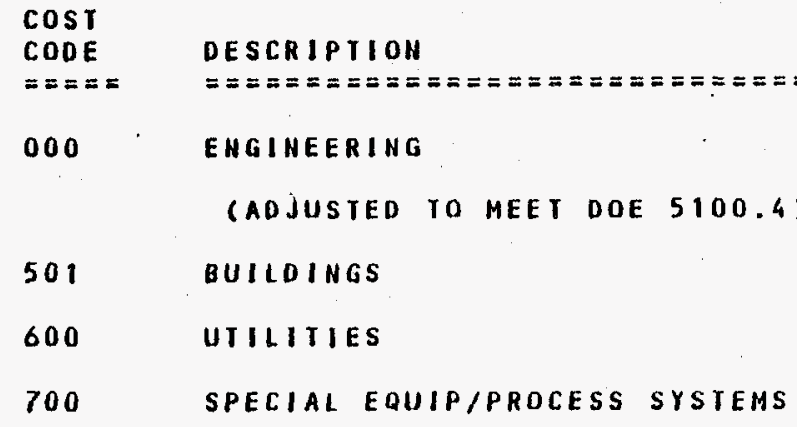

(ADJUSIED TO MEET DOE 5100.4)

$\stackrel{\rho}{1}$
TOIAL ESTIMATED CONSTRUCTION COST

900
OTIIER PROJECT COST

(ADJUSTED TO MEET DOE 5100.4 )

TOIAL PROJECY COST

\begin{tabular}{|c|c|c|c|}
\hline ESCALATED & \multicolumn{2}{|c|}{ CONTIHGENCY } & TOTAL \\
\hline $\begin{array}{l}\text { TOTAL COST } \\
==========\end{array}$ & $=\approx \%==$ & 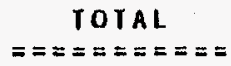 & $\begin{array}{c}\text { DOLLARS } \\
=======\end{array}$ \\
\hline $1,330,000$ & 15 & 200,000 & $1,530,000$ \\
\hline $.30,000$ & & 0 & $-30,000$ \\
\hline 410,000 & 20 & 80,000 & 490,000 \\
\hline $6,370,000$ & 18 & $1,150,000$ & $7,520,000$ \\
\hline 280,000 & 20 & 60,000 & 340,000 \\
\hline 40,000 & & 10,000 & 50,000 \\
\hline
\end{tabular}

(1)

$8,400,000$

$1,500,000$

$9.900,000$

$1,800,000$

$0 \quad 1,800,000$

0

0

0

$10,200,000$

15

$1,500,000$

$11,700,000$

$\int_{-}^{-}$

$$
\text { . }
$$


KAISER ENGINEERS HANFORD HESIINGHOUSE HANFORD COMPAHY JOB NO. LOTO/ER4561

FILE NO, LOTOBAC4

NBS DESCRIPIION

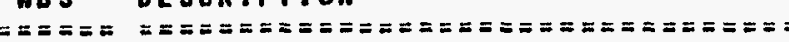

111010 CATEGORY 1 DESIGN

112010 CAIEGORY 2 DESIGN

SUBTOIAL 11 DEFINITIVE DESIGN

120000 CONSIRUCIION EHG/INSP

SUGTOTAL 1 ENGINEERING

310010 VACUUM PROCESS SEWER

310020 RETENTION PROCESS SEHER

310030 PRESSURE SEHER SYSIEM

SUBTOTAL 31 FORCE ACCOUNT CONSTRUCTION

320010 VACUUM PROCESS SEHER

320020 RETENTION PROCESS SEUER

320030 PRES SURE SEHER SYSTEH

320035 LIFT STATIOHS

320040 COLLECTION STATION

320050 SATELLITE COLLECTION STATIOI

320060 ELECTRICAL-COLLECTION STATIONS

SUBTOTAL 32 FIXED PRICE CONSTRUCTION

\section{$3300000 / C$ CONSTRUCTION}

SUBTOTAL 33 CONSTRUCTION-O/C

SUBTOTAL 3 CONSTRUCTION

\section{PROJECT INTERGRATION}

SUBTOTAL 4 PROJECT INIEGRATION

500001 OIHER PROJECT COSI - IO DAIE
* * IEST : INTERACIIVE ESTIMAIIHG * *

300 AREA PROCESS SEUER PIPING UPGRADE CONCEPIUAL ESIIMAIE

DOE_RO2 - WORK BREAKDOWN STRUCTURE SUMMARY
PAGE 2 OF 11

DATE $02 / 24 / 94 \quad 06: 17: 32$

BY KLR/JJM/LGH/KDE

\begin{tabular}{|c|c|c|c|c|c|c|c|c|}
\hline ESTIMATE & ONSITE & SuB & ESCA & ILATION & sur & COHII & NGENCY & TOTAL \\
\hline SUBTOTAL & INDIRECTS & TOTAL & $x$ & TOTAL & TOTAL & $x$ & TOTAL & DOLLARS \\
\hline$== \pm= \pm==2$ & $===-=\equiv=\equiv=$ & $=== \pm==2==$ & $=\approx= \pm=-$ & $== \pm=\pi==$ & $==== \pm==$ = = & & 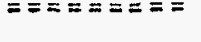 & \\
\hline $\begin{array}{l}524285 \\
462370\end{array}$ & $\begin{array}{l}0 \\
0\end{array}$ & $\begin{array}{l}524285 \\
462370\end{array}$ & $\begin{array}{l}0.00 \\
0.00\end{array}$ & $\begin{array}{l}0 \\
0\end{array}$ & $\begin{array}{l}524285 \\
462370\end{array}$ & $\begin{array}{l}15 \\
15\end{array}$ & $\begin{array}{l}78644 \\
69357\end{array}$ & $\begin{array}{l}602929 \\
531727\end{array}$ \\
\hline 986655 & 0 & 986655 & 0.00 & $\mathbf{0}$ & 986655 & 15 & 148001 & 1134656 \\
\hline 323255 & 0 & 323255 & 5.91 & 19104 & 342359 & 15 & 51353 & 393712 \\
\hline 1309910 & D & 1309910 & 1.46 & 19104 & 1329014 & 15 & 199354 & 1528368 \\
\hline $\begin{array}{l}706145 \\
245420 \\
146265\end{array}$ & $\begin{array}{l}0 \\
0 \\
0\end{array}$ & $\begin{array}{l}706145 \\
245420 \\
146265\end{array}$ & $\begin{array}{l}6.32 \\
6.32 \\
6.32\end{array}$ & $\begin{array}{r}44620 \\
15511 \\
9244\end{array}$ & $\begin{array}{l}750773 \\
260931 \\
155509\end{array}$ & $\begin{array}{l}20 \\
20 \\
20\end{array}$ & $\begin{array}{r}150155 \\
52186 \\
31102\end{array}$ & $\begin{array}{l}900928 \\
313117 \\
186611\end{array}$ \\
\hline 1097830 & 0 & 1097830 & 6.32 & 69383 & 1167213 & 20 & 233443 & 1400656 \\
\hline $\begin{array}{r}1900016 \\
373697 \\
432720 \\
245679 \\
340025 \\
120684 \\
98588\end{array}$ & $\begin{array}{r}323003 \\
63528 \\
73562 \\
41766 \\
57804 \\
20516 \\
16760\end{array}$ & $\begin{array}{r}2223019 \\
437225 \\
506282 \\
287445 \\
397829 \\
141200 \\
115348\end{array}$ & $\begin{array}{l}6.02 \\
6.02 \\
6.02 \\
6.02 \\
6.02 \\
6.02 \\
6.02\end{array}$ & $\begin{array}{r}133826 \\
26321 \\
30478 \\
17304 \\
23948 \\
8500 \\
6944\end{array}$ & $\begin{array}{r}2356844 \\
463546 \\
536761 \\
304748 \\
421780 \\
149700 \\
122292\end{array}$ & $\begin{array}{l}20 \\
20 \\
20 \\
20 \\
20 \\
20 \\
20\end{array}$ & $\begin{array}{r}471369 \\
92709 \\
107352 \\
60949 \\
84356 \\
29940 \\
24458\end{array}$ & $\begin{array}{r}2828213 \\
556256 \\
644113 \\
365699 \\
506134 \\
179640 \\
146751\end{array}$ \\
\hline 3511409 & 596939 & 4108348 & 6.02 & 247321 & 4355671 & 20 & 871133 & 5226806 \\
\hline 866880 & 0 & 866880 & 6.32 & 54787 & 921667 & 20 & 184333 & 1106000 \\
\hline 866880 & 0 & 866880 & 6.32 & 54787 & 92.1667 & 20 & 184333 & 1106000 \\
\hline 5476119 & 596939 & 6073058 & 6.12 & 371491 & 6444551 & 20 & 1288909 & 7733462 \\
\hline 599982 & 0 & 599982 & 3.48 & 20879 & 620861 & 0 & 0 & 620861 \\
\hline 599982 & 0 & 599982 & 3.48 & 20879 & 620861 & 0 & 0 & 620861 \\
\hline 600000 & 0 & 600000 & 0.00 & 0 & 600000 & 0 & 0 & 600000 \\
\hline
\end{tabular}


KAISER ENGIHEERS HAHFORD

WESTINGHOUSE HAHFORD COHPANY

JOB NO. LOTO/ER4561

F JLE HO. LOTOBAC4

HBS DESCRIPIION

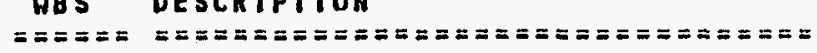

500002 OTHER PROJECT COST - FY 194 500003 OTHER PROJECT COST - FY 195

500004 OTHER PROJECT COST - FY 96

500005 OIHER PROJECT COST - FY 197

SUBJOIAL 5

OTHER PROJECT COST

PROJECT TOTAL
* * IEST - INIERACTIVE ESTIMATING * *

300 AREA PROCESS SEWER PIPING UPGRADE CONCEPTUAL. ESTIMATE

DOE_ROZ - WORK BREAKDOWN STRUCTURE SUMMARY
PAGE 3 OF 11

DATE 02/24/94 06:17:33

BY KLR/JJM/LGH/KOE

\begin{tabular}{|c|c|c|c|c|c|c|c|c|}
\hline $\begin{array}{l}\text { ESIIMATE } \\
\text { SUBTOIAL } \\
==\approx===\approx=\end{array}$ & $\begin{array}{l}\text { ONSITE } \\
\text { INDIRECYS } \\
==\approx= \pm \approx== \pm\end{array}$ & $\begin{array}{c}\operatorname{SUB} \\
\operatorname{rOTAL} \\
=== \pm== \pm=\end{array}$ & $===\approx==$ & $\begin{array}{l}\text { ILATIOH } \\
\text { TOIAL } \\
==\approx====\end{array}$ & $\begin{array}{c}\text { SUB } \\
\operatorname{rOTAL} \\
==\approx==\approx==\end{array}$ & $\begin{array}{c}\operatorname{CONT} \\
= \pm= \pm=\end{array}$ & $\begin{array}{l}\text { I HGEHCY } \\
\text { TOTAL } \\
===\approx=z==\end{array}$ & $\begin{array}{c}\text { TOTAL. } \\
\text { OOLLARS } \\
== \pm= \pm=\equiv=\end{array}$ \\
\hline $\begin{array}{l}230000 \\
342000 \\
375000 \\
205000\end{array}$ & $\begin{array}{l}0 \\
0 \\
0 \\
0\end{array}$ & $\begin{array}{l}230000 \\
342000 \\
375000 \\
205000\end{array}$ & $\begin{array}{l}0.00 \\
2.33 \\
5.28 \\
8.42\end{array}$ & $\begin{array}{r}0 \\
7969 \\
19800 \\
17261\end{array}$ & $\begin{array}{l}230000 \\
349969 \\
394800 \\
222261\end{array}$ & $\begin{array}{l}0 \\
0 \\
0 \\
0\end{array}$ & $\begin{array}{l}0 \\
0 \\
0 \\
0\end{array}$ & $\begin{array}{l}230000 \\
349969 \\
394800 \\
222261\end{array}$ \\
\hline 1752000 & 0 & 1752000 & 2.57 & 45030 & 1797030 & 0 & 0 & 1797030 \\
\hline
\end{tabular}

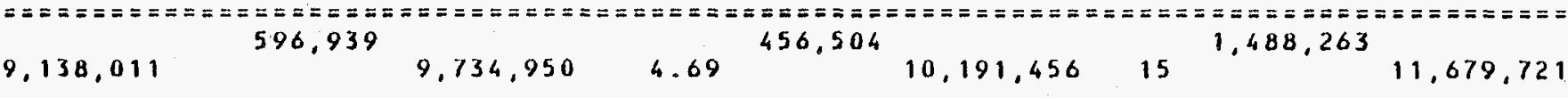


1. DOCUMEHTS AND DRAHINGS

\section{DOCUNEMTS AND DRAHINGS}

DOCUAENIS: ADVANCED CONCEPTUAL DESIGN REPORT DATED JANUARY 1994 (ISSUE E) PRELIMINARY

DRAHINGS: ES-07OV-C2 K2 TIROUGH K21 (20 TOTAL)

2. MATERIAL PRICES

$=========== \pm$

UNIT COSTS REPRESEHT CURRENT PRICES FOR SPECIFIED MAIERIAL.

3. LABOR RATES

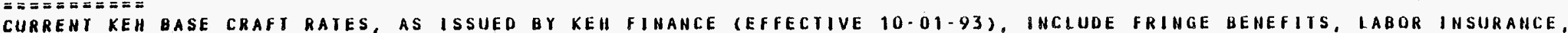

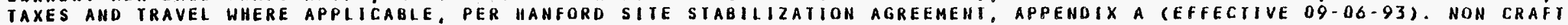

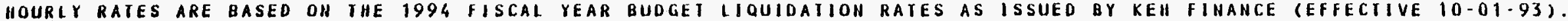

4. GEMERAL REQUIREMENTS/TECHHICAL SERVICES/OVERHEADS

GEMERAL REQUIRENENTS/TECHNICAL SERVICES

A.) ONSITE CONSTRUCIION FORCES GENERAL REQUIREMENTS, TECHNICAL SERVICES AND CRAFT DVERHEAD COSTS ARE INCLUDED AS A COMPOSITE PERCENTAGE BASED ON THE KEH ESTIMATING FACTOR/BILLING SCHEDULE, REVISION I6. DATEO OCTOBER OI, 1993. IHE TOTAL COMPOSITE PERCENTAGE APPLIED TO ONSITE CONSTRUCTION FORCES LABOR, FOR IHIS PROJECT, IS 93\% FOR SHOP HORK AND 134\% FOR FIELD WORK, WHICH IS REFLECIED IN THE "OH\&P/B\&I" COLUMN OF THE ESTIMATE DETAIL.

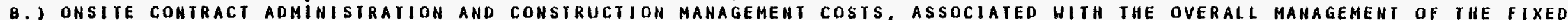
PRICE CONTRACYS, ARE INCLUDED AS A COMPOSITE PERCENTAGE AMD LUMP SUM ALLOHANCE (FOR BID PACKAGE PREP) BASED ON THE ESTIMATING FACIOR/BILLING SCHEDULE. THE TOIAL COMPOSITE PERCENTAGE AHD LUMP SUM ALLOHANCE ARE APPLIED AGAINST THE IOTAL FIXEO PRICE COHTRACT AHOUNT WHICH IS REFLECTED ON THE KEH SUMMARY REPORT DOEROT, INCLUDED HITII TIIS ESTIMATE. (FINAL ESTIMATES MAY BE PARTIALLY MANLOADED AND INCLUDED WITIIIN THE ESTIMATE DETAIL)

C.) FIXED PRICE CONTRACTOR OVERHEAD, PROFIT, BOHD AHD IHSURAHCE COSTS HAVE BEEH APPLIED AT THE FOLLOHIHG PERCEHTAGES AMD ARE REFLECTED IN THE "OH\&P/B\&I" COLUMN OF THE ESTIMATE DETAIL:

LABOR - $15 \%$ MATERIAL $-15 \%$ SUBCONTRACTS - $5 \%$

5. ESCALATIOH

ESCALATION PERCENTAGES HERE CALCULATED BY THE HANFORD MATERIAL \& LABOR ESCALATION STUDY, DATED FEBRUARY I993.

\section{ROUHDING}

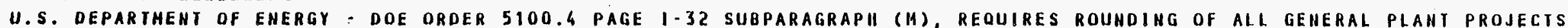
(GPP'S) AND LINE ITEM (LI) COST ESTIMATES. REFERENCE: DOE 5100.4, FIGURE I-11, DATED IO-31-B4.

\section{REMARKS}

$======$

A.) ASSUME SHORING HILL BE USED FOR MORE IIIAN ONE BUFFER STATION.

B.) BARRICADES INCLUDE SIGNS, FLAGGIHG, AND CONSIRUCIION FENCE.

C.) ALL PRESSURE PIPE IRENCHES FIGURED TO BE 3\% HIDE BY 6. DEEP.

D.) ASSUHE ASPHALT REPAIR TO AVERAGE 61 HIDE

E.) ASSUHE GRAVEL STABILIZATION TO AVERAGE 15 ' HIDE.

F.) AH ALLOHANCE HAS USED FOR CONCRETE REMOVAL AND REPAIR. 
* IEST - INTERACIIVE ESTIMATING * *

300 AREA PROCESS SEHER PIPING UPGRADE

CONCEPTUAL ESTIMATE
DOE_RO3. ESTIMATE BASIS SHEET
PAGE 5 OF 11

DATE $02 / 24 / 94 \quad 16: 42: 17$

BY KLR/JJM/LGH/KDE

G.) AN ALLOHAHCE WAS USED FOR HAND LOCATIHG EXISTING UHDERGROUNO UIILITIES.

H.) AS SUME ALL BURIAL TO BE LOW LEVEL WASTE.

1.) ASSUME 20\% OF ALL EARTH EXCAVAIED IN RADIATION AREAS TO BE HAULED OFF AND BURIED AS LOH LEVEL HASTE.

J.) ESTIMATE DOES NOT INCLUDE AHY MASK HORK.

K.) ASSUME ALL BACKFILL TO BE DONE HIIII MACHINE ASSISTANCE.

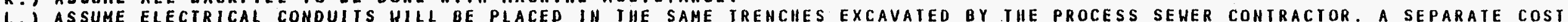
FOR ELECTRICAL EXCAVATION IS NOT IMCLUDED.

M.) OPC COST PROVIDED BY KEII PM

N.) PROJECT UPGRADE PROVIDED BY KE II PM.

O.) PROJECT INTEGRATION COSTS AND OPC COSTS IIAVE HO CONIIGNeCY APPLIED TO THEM PER KE PM. 
WHC-SD-L070-PMP-001, Rev. 0

\section{ATTACHMENT D}

\section{SPECIFIC PARTICIPANTS}

$D-0$ 


\section{Specific Participants}

\begin{tabular}{|c|c|c|c|}
\hline Function/Organization & Name & MSIN & Phone \\
\hline RL AME Project Engineer & G. R. Mezger & A5-18 & $6-5039$ \\
\hline RL Programs & E. A. Green & $63-18$ & $6-1572$ \\
\hline Project Integrator & H. E. Wellsfry & $\llcorner 4-93$ & $2-0812$ \\
\hline HHC Project Engineer & K. Lane & L4-93 & $6-7691$ \\
\hline WHC Programs - LE & J. A. Eacker/O. H. Bradt & L6-04 & 6.9988 \\
\hline KEH Landlord Program & K. D. Hayden & 63.09 & $6-4429$ \\
\hline KEH Landlord Program & K. Nelson-Jensen & $63-09$ & $6-3150$ \\
\hline HHC Operations - 300 Area & D. H. Lindsey & L6-04 & $2-3087$ \\
\hline KEH site Planning & K. S. Daly & $63-10$ & $6-7547$ \\
\hline WHC Industrial Safety & D. B. Tullis & N1-80 & $2-0770$ \\
\hline WHC Envirormental & K. S. Tollefson & H6-21 & $2-2234$ \\
\hline WHC Quality Assurance & M. C. Arntzen, Jr & $\lcm{14-93}$ & $2-3305$ \\
\hline XEH Electrical Utilities & L. C. Groner & $\$ 2-12$ & $3-2756$ \\
\hline WHC HPT & D. R. Ekstrom & $16-52$ & $6-1135$ \\
\hline WHC Permitting & R. J. Swan & H6-21 & $6-0967$ \\
\hline HHC Regulatory Analysis & R. J. Swan & H6-21 & 6.0967 \\
\hline WHC CERCLA Interface & G. C. Henckel III & $\mathrm{H} 6-04$ & 6-1994 \\
\hline WHC Fire Protection & D. G. Parthree & L6-51 & $6-0394$ \\
\hline WHC Central Engineering & S. White & H5-72 & $2-3236$ \\
\hline WHC Process Engineering & A. R. Ol ander & $\mathbf{L 6}-04$ & $3-3643$ \\
\hline WHC Enviromental Safety Assurance & F. A. Schmorde & $10-24$ & $6-0080$ \\
\hline WHC SAD Development & R. 8. Bendixsen & $\mathrm{H} 4-7 \mathrm{O}$ & $6-9523$ \\
\hline WHC security & B. C. Harmer & GS-15 & $6-1179$ \\
\hline WHC Instrumentation \& Control & R. Whitehurst & $N 1-42$ & $6-4663$ \\
\hline HHC Instrumentation \& Control & C. H. Dickey & $63-15$ & $6-7424$ \\
\hline WHC Document Control & C. M. Dunnum & $R 1-28$ & $3-3834$ \\
\hline KEH Construction Management & J. H. Mortimer & $44-95$ & 6.5505 \\
\hline PNL Interface & A. S. Ikenberry & $P 7-68$ & $6-0963$ \\
\hline BCSR Interface & H. E. Eaton & $A 2-35$ & $6-9453-15$ \\
\hline KEH Engineering/Civil & K. D. Bare & $67-55$ & $2-2755$ \\
\hline XEH Engineering/Mechanical & T. Ambal am & $E 6-46$ & 6.6049 \\
\hline KEH Engineering/Electrical & C. L. Sublett & G7-52 & $2-2435$ \\
\hline SCM Engineering/Civil-Sanitary & Jim Lauer & Fort Wayne, iN & $(219) 485-6312$ \\
\hline
\end{tabular}


WHC-SD-L070-PMP-001, Rev. 0

ATTACHMENT E

ENVIRONMENTAL POINT OF CONTACT CHECXLIST

$E-0$ 
From: Regulatory Program Integration

Phone: $\quad 376-0967$ H6-30

Date: January 13, 1994

Subject: POINT OF CONTACT CHECKLIST FOR THE 300 AREA PROCESS SEWER REPLACEMENT

To: G. Dragseth

CC: J. A. Bates

R. C. Bowman

D. J. Carrel

J. J. Dorian

D. B. Encke

R. H. Engelmann

B. G. Erlandson

K. A. Gano

K. A. Giese
L4-93

H6-22

H6-24

H6-22

H6-30

$\times 5-55$

H6-26

H6-20

$\mathrm{X} 0-21$

H6-25

88110-RJS-93-129 


$$
\begin{array}{r}
\text { WHC-SD-L070-PMP-001, R'ev. } 0 \\
\text { 93-POC-078 } \\
\text { 88110-RJS-93-129 } \\
\text { Page 1 of } 11
\end{array}
$$

\title{
SCOPE OF WORK \\ 300 AREA PROCESS SEMER REPLACEMENT
}

\begin{abstract}
This Point of Contact (POC) checklist evaluates the environmental requirements for the 300 Area Process Sewer Upgrade System (Project L-070). Project L-070 involves the construction and operation of a new process sewer collection system which will discharge effluents to the 300 Area Treated Effluent Disposal Facility (TEDF), Project L-045. Discharge of waste water may also be pumped from TEDF to the Richland Publicly Owned Treatment Horks, as part of Project V-784.
\end{abstract}

Effluents discharged from L-070 to L-045, and permitting activities related to releases to the river (or associated construction), will be dealt with through L-045. Remaining sewer pipes are to be removed from service and eventually disposed of as part of the 300 Area CERCLA program.

The existing 300 Area Process Sewer System is primarily a gravity system (supplemented by two lift stations) that discharges facility process waste water to the soil column at the 300 Area process trenches. Present effluents are now drained by gravity to existing trenches where they are discharged to the soil column.

Two proposed actions have been selected as viable alternatives to upgrading the 300 Area process sewer system.

Alternative \#1 - Construction and operation of a new pressurized process sewer collection system consisting of approximately 48 lift stations and more than 25,000 feet of buried polyvinyl chloride, or similar pipe. Each lift station would consist of two submersible pumps installed in a wet pit constructed of concrete. The lift stations would be monitored by an alarm station 24 hours per day, and be equipped. with a duplex pump system including controls, and switchgear. The new lift stations would, in most cases, be connected to the existing drain pipes from the buildings and would be gravity fed from the buildings. The new process sewer pipes would tie into the new lift stations.

Alternative \#2 - Installation of a vacuum collection system will consist of a central vacuum station, vacuum collection piping, and collection sumps with vacuum valves. The vacuum station building would be located in the 300 Area and would contain duplex vacuum pumps, a vacuum reservoir tank, a water collection tank, and water discharge pumps and controls. Normally, the vacuum pumps maintain the vacuum system. The water collection tank would discharge through pumps to the collection sump/lift station for the TEDF. About 36 collection sumps would be installed, with one near each of the buildings to be connected to the system. Each sump would contain a vacuum valve and controls. Advantages of the vacuum system, compared to the pressure system, are potentially less initial capital costs, fewer maintenance and operating problems, a less complex system, and an environmentally safer system because pipe breaks would not result in pressurized leakage of liquids into the soil. 
WHC-SD-L070-PMP-001, Rev. 0

93-POC-078

88110-RJS-93-129

Page 2 of 11

ENVIRONMENTAL POINT OF CONTACT CHECXLIST

SUMMARY LIST OF POTENTIAL PERMITS AND APPROVALS

\begin{tabular}{|c|c|c|c|c|c|}
\hline $\begin{array}{c}\text { Environmental } \\
\text { Media } \\
.\end{array}$ & $\begin{array}{l}\text { Permit, } \\
\text { Approval, or } \\
\text { Requirement }\end{array}$ & Regulation & $\begin{array}{l}\text { Regul atory } \\
\text { Agency }\end{array}$ & Restriction & $\begin{array}{c}\text { Applicable } \\
(Y \text { or } N) \\
\text { * See } \\
\text { narrative }\end{array}$ \\
\hline NEPA & $\begin{array}{l}\text { NEPA } \\
\text { Documentation }\end{array}$ & 10 CFR 1021 & DOE & $\begin{array}{l}\text { Title II } \\
\text { Design } \\
\text { (Projects), } \\
\text { Procurement }\end{array}$ & Y \\
\hline SEPA & SEPA & WAC $197-11$ & $\begin{array}{l}\text { State } \\
\text { Agency }\end{array}$ & $\begin{array}{l}\text { License, } \\
\text { Permit }\end{array}$ & $\begin{array}{c}* \text { To Be } \\
\text { Determined }\end{array}$ \\
\hline \multirow[t]{4}{*}{ Air Emissions } & NESHAPS & $\begin{array}{l}40 \text { CFR } 61 \\
\text { Subpart H }\end{array}$ & EPA & Construction & $Y$ \\
\hline & RAEP & WAC $246-247$ & $\mathrm{DOH}$ & $\begin{array}{l}\text { Construction } \\
\text { Operation }\end{array}$ & Y \\
\hline & NOC & $\begin{array}{l}\text { WAC } 173-400 \\
\text { WAC } 173-460 \\
\text { BFCAA Reg. } 80-7\end{array}$ & $\begin{array}{l}\text { Ecology } \\
\text { BFCAA }\end{array}$ & Construction & $\begin{array}{c}\text { * To Be } \\
\text { Determined }\end{array}$ \\
\hline & PSD & WAC $173-400$ & $\begin{array}{l}\text { Ecology } \\
\text { BFCAA }\end{array}$ & Construction & $\begin{array}{c}\text { * To Be } \\
\text { Determined }\end{array}$ \\
\hline Asbestos & $\begin{array}{l}\text { Notice of } \\
\text { Intent }\end{array}$ & $\begin{array}{l}\text { BFCAA } \\
\text { Article } 10 \\
40 \text { CFR } 61, \\
\text { Subpart M }\end{array}$ & BFCAA & $\begin{array}{l}\text { Prior to } \\
\text { Working with } \\
\text { Asbestos }\end{array}$ & N \\
\hline Fire & Fire Permit & WAC $173-425$ & $\begin{array}{l}\text { Hanford } \\
\text { Fire } \\
\text { Department }\end{array}$ & Open Burning & N \\
\hline \multirow{3}{*}{$\begin{array}{l}\text { Soil Column } \\
\text { Waste Water } \\
\text { Disposal }\end{array}$} & SWDP & WAC $173-216$ & Ecology & Operation & $N$ \\
\hline & $\begin{array}{l}\text { Approval of } \\
\text { Engr: Rpt., } \\
\text { Plans \& } \\
\text { Specs., and ? } \\
\text { O\&M Manual }\end{array}$ & WAC $173-240$ & Ecology & Construction & $\begin{array}{c}\text { *To Be } \\
\text { Determined } \\
\end{array}$ \\
\hline & $\begin{array}{l}\text { UIC Permit/ } \\
\text { Registration }\end{array}$ & WAC $173-218$ & Ecology & Operation & $\mathrm{N}$ \\
\hline
\end{tabular}


WHC-SD-L070-PMP-001, Rev. 0

93-POC-078

88110-RJS-93-129

Page 3 of 11

\begin{tabular}{|c|c|c|c|c|c|}
\hline $\begin{array}{l}\text { Environmental } \\
\text { Media }\end{array}$ & $\begin{array}{l}\text { Permit, } \\
\text { Approval, or } \\
\text { Requirement }\end{array}$ & Regulation & $\begin{array}{l}\text { Regulatory } \\
\text { Agency }\end{array}$ & Restriction & $\begin{array}{c}\text { Applicable } \\
(Y \text { or } N) \\
* \text { See } \\
\text { narrative }\end{array}$ \\
\hline \multirow[t]{5}{*}{$\frac{\text { Domestic }}{\text { Waste Water }}$} & $\begin{array}{l}\text { Septic } \\
\text { Systems } \\
<14,500 \text { gpd } \\
\text { Capacity } \\
\text { Design } \\
\text { Approval } \\
\end{array}$ & WAC 246-272 & $\mathrm{DOH}$ & Construction & N \\
\hline & $\begin{array}{l}\text { Septic } \\
\text { Systems } \\
>14,500 \text { gpd } \\
\text { Capacity } \\
\text { Design } \\
\text { Approval } \\
\end{array}$ & WAC $173-216$ & Ecology & Construction & N \\
\hline & $\begin{array}{l}\text { Pretreatment } \\
\text { Permit }\end{array}$ & $\begin{array}{l}40 \text { CFR } 403, \\
\text { City Ordinance }\end{array}$ & $\begin{array}{l}\text { City of } \\
\text { Richland }\end{array}$ & $\begin{array}{l}\text { Discharge to } \\
\text { City Sewage } \\
\text { Facility }\end{array}$ & N \\
\hline & $\begin{array}{l}\text { Operator } \\
\text { Certification }\end{array}$ & WAC $173-230$ & Ecology & Operation & N \\
\hline & $\begin{array}{l}\text { Discharge } \\
\text { Standards }\end{array}$ & WAC $173-221$ & Ecology & Discharge & N \\
\hline \multirow{7}{*}{$\begin{array}{l}\frac{\text { Surface }}{\text { Waste Water }} \\
\text { Disposal }\end{array}$} & NPDES Permit & 40 CFR 122 & EPA & Operation & $N$ \\
\hline & $\begin{array}{l}\text { Storm Water } \\
\text { Discharge } \\
\text { Under General } \\
\text { Permit }\end{array}$ & 57 FR No. 175 & EPA & $\begin{array}{l}\text { River } \\
\text { Construction }\end{array}$ & N \\
\hline & $\begin{array}{l}\text { Dredge \& Fill } \\
\text { Permit }\end{array}$ & 33 CFR 320,323 & $\operatorname{COE}$ & $\begin{array}{l}\text { River } \\
\text { Construction }\end{array}$ & $N$ \\
\hline & $\begin{array}{l}\text { Section } 10 \\
\text { Permit }\end{array}$ & 33 CFR 320,322 & COE & $\begin{array}{l}\text { River } \\
\text { Construction }\end{array}$ & N \\
\hline & $\begin{array}{l}\text { Nationwide } \\
\text { Permits }\end{array}$ & 33 CFR 330 & COE & $\begin{array}{l}\text { River } \\
\text { Construction }\end{array}$ & N \\
\hline & $\begin{array}{l}\text { Hydraulic } \\
\text { Projects } \\
\text { Permit } \\
\end{array}$ & WAC $220-110$ & $\begin{array}{l}\text { WA Dept. } \\
\text { of } \\
\text { Fisheries }\end{array}$ & $\begin{array}{l}\text { River } \\
\text { Construction }\end{array}$ & N \\
\hline & $\begin{array}{l}\text { Shoreline } \\
\text { Development } \\
\text { Permit }\end{array}$ & WAC $173-14-20$ & $\begin{array}{l}\text { Benton } \\
\text { County }\end{array}$ & $\begin{array}{l}\text { River/Island } \\
\text { Construction }\end{array}$ & N \\
\hline
\end{tabular}


WHC-SD-L070-PMP-001, Rev. 0

93-POC-078

88110-RJS-93-129

Page 4 of 11

\begin{tabular}{|c|c|c|c|c|c|}
\hline$\frac{\text { Environmental }}{\text { Media }}$ & $\begin{array}{l}\text { Permit, } \\
\text { Approval, or } \\
\text { Requirement }\end{array}$ & Regulation & $\begin{array}{l}\text { Regul atory } \\
\text { Agency }\end{array}$ & Restriction & $\begin{array}{c}\text { Appl icable } \\
(Y \text { or } N) \\
\text { * See } \\
\text { narrative }\end{array}$ \\
\hline & $\begin{array}{l}\text { Aquatic Lands } \\
\text { Lease }\end{array}$ & WAC $332-30$ & $\begin{array}{l}\text { WA Dept. } \\
\text { of } \\
\text { Natural } \\
\text { Resources } \\
\end{array}$ & Construction & $N$ \\
\hline & $\begin{array}{l}\text { Hanford Reach } \\
\text { Study Act } \\
\text { Notification }\end{array}$ & PL $100-605$ & $\begin{array}{l}\text { U.S. Parks } \\
\text { Service }\end{array}$ & $\begin{array}{l}\text { Construction } \\
\text { Within } 1 / 4 \\
\text { Mi. of River }\end{array}$ & N \\
\hline & $\begin{array}{l}\text { Water Quality } \\
\text { Modification } \\
\text { Permit }\end{array}$ & WAC 173-201 & Ecology & $\begin{array}{l}\text { River } \\
\text { Construction }\end{array}$ & N \\
\hline & $\begin{array}{l}\text { Certification } \\
\text { of NPDES } \\
\text { Permit }\end{array}$ & 40 CFR 121 & Ecology & Operation & N \\
\hline & $\begin{array}{l}\text { Categorical } \\
\text { Standards }\end{array}$ & 40 CFR $405-471$ & EPA & Operation & $\mathrm{N}$ \\
\hline \multirow[t]{3}{*}{$\frac{\text { Drinking }}{\text { Water SuppTy }}$} & $\begin{array}{l}\text { Approval of } \\
\text { Engr. Rpt., } \\
\text { Plans \& Spec. }\end{array}$ & WAC $246-290$ & $\mathrm{DOH}$ & Construction & $N$ \\
\hline & System ID.\# & WAC $246-290$ & $\mathrm{DOH}$ & Operation & $\mathrm{N}$ \\
\hline & $\begin{array}{l}\text { Operator } \\
\text { Certification }\end{array}$ & WAC $246-292$ & $\mathrm{DOH}$ & Operation & N \\
\hline Solid Waste & $\begin{array}{l}\text { Solid Waste } \\
\text { Handling } \\
\text { Facility } \\
\text { Permit }\end{array}$ & WAC $173-304$ & BFHD & Construction & N \\
\hline $\begin{array}{l}\text { Dangerous } \\
\text { Waste }\end{array}$ & $\begin{array}{l}\text { Dangerous } \\
\text { Waste Permit } \\
\text { (RCRA - A/B) }\end{array}$ & $\begin{array}{l}\text { WAC 173-303 \& } \\
40 \text { CFR } 264, \\
265,270\end{array}$ & Ecology & $\begin{array}{l}\text { Construction } \\
\text { of New } \\
\text { Facilities } \\
\text { or Expansion } \\
\text { of Existing } \\
\text { Facilities } \\
\end{array}$ & N \\
\hline $\begin{array}{l}\text { Underground } \\
\text { Storage Tanks }\end{array}$ & Tank Permit & WAC $173-360$ & Ecology & Operation & N \\
\hline Al1 Media & $\begin{array}{l}\text { Floodplain } \\
\text { Wet land } \\
\text { Assessment }\end{array}$ & 10 CFR 1022 & DOE & $\begin{array}{l}\text { Any Surface } \\
\text { Disturbance }\end{array}$ & N \\
\hline
\end{tabular}


WHC-SD-L070-PMP-001, Rev. O

93-POC-078

88110-RJS-93-129

Page 5 of 11

\begin{tabular}{|c|c|c|c|c|c|}
\hline $\begin{array}{l}\text { Environmental } \\
\text { Media }\end{array}$ & $\begin{array}{l}\text { Permit, } \\
\text { Approval, or } \\
\text { Requirement }\end{array}$ & Regulation & $\begin{array}{l}\text { Regulatory } \\
\text { Agency }\end{array}$ & Restriction & $\begin{array}{c}\text { Applicable } \\
(Y \text { or } N) \\
\text { * See } \\
\text { narrative }\end{array}$ \\
\hline & $\begin{array}{l}\text { Cultural } \\
\text { Resource } \\
\text { Review } \\
\text { Clearance }\end{array}$ & 36 CFR 800 & DOE & $\begin{array}{l}\text { Surface } \\
\text { Disturbing } \\
\text { Activities \& } \\
\text { Modification } \\
\text { of Bldgs } \\
\text { Eligible for } \\
\text { Listing on } \\
\text { Historical } \\
\text { Register }\end{array}$ & Y \\
\hline & $\begin{array}{l}\text { Excavation } \\
\text { Permit }\end{array}$ & 36 CFR 800 & DOE & $\begin{array}{l}\text { Excavation } \\
\text { Project }\end{array}$ & Y \\
\hline & $\begin{array}{l}\text { Endangered } \\
\text { Species } \\
\text { Approval } \\
\end{array}$ & 50 CFR 402.6 & $\begin{array}{l}\text { Fish and } \\
\text { Wildl ife } \\
\text { Service } \\
\end{array}$ & $\begin{array}{l}\text { Construction } \\
\text { Habitat } \\
\text { Modification }\end{array}$ & Y \\
\hline & $\begin{array}{l}\text { Preoperation } \\
\text { Monitoring of } \\
\text { Facilities, } \\
\text { Sites, \& } \\
\text { Operations } \\
\end{array}$ & $\begin{array}{l}\text { DOE Order } \\
5400.1\end{array}$ & DOE & Operation & $Y$ \\
\hline & $\begin{array}{l}\text { Radiation } \\
\text { Protection } \\
\text { Standards } \\
\end{array}$ & $\begin{array}{l}\text { DOE Order } \\
5400.5\end{array}$ & $D O E$ & Construction & Y \\
\hline & $\begin{array}{l}\text { Facility Fire } \\
\text { Protection } \\
\text { Standards }\end{array}$ & $\begin{array}{l}\text { DOE Order } \\
5480.7\end{array}$ & DOE & Construction & N \\
\hline
\end{tabular}




\section{NATIONAL ENVIRONMENTAL POLICY ACT (NEPA)}

NEPA Documentation - 10 Code of Federal Regulations (CFR) 1021

A NEPA review is required for a 17 proposed actions at the Hanford Site. Documentation of the completed NEPA review process could include an Environmental Impact Statement (EIS), an Environmental Assessment (EA) or a Categorical Exclusion (CX). The EIS is required for proposed actions significantly affecting the quality of the human environment. In cases where it is uncertain whether an EIS is required, an EA is prepared. CXS by DOE from the requirement to prepare an EIS or EA are possible if the proposed action clearly would have no significant impact on the quality of the human environment. However, any action that is determined categorically excludable still requires documentation.

Note: All cultural resource surveys and ecological survey/reviews must be completed before any NEPA paperwork is submitted to RL.

\section{Evaluation:}

A draft EA/Finding of No Significant Impact (EA/FONSI) were completed and submitted to RL on March 10, 1993. The EA/FONSI were revised to include the TEDF discharge to the Richland Publicly Owned Treatment Works option and resubmitted to RL on June 15, 1993. Comments were received from RL on September 27, 1993. The revised EA/FONSI was resubmitted to RL on 0ctober 8, 1993, and they are presently reviewing the document. Contact Mr. R. H. Engelmann, 376-7485, for additional information.

\section{STATE ENVIRONMENTAL POLICY ACT (SEPA)}

\section{SEPA Documentation - WAC 197-11}

SEPA is the state or Tocal equivalent of NEPA that requires evaluation of environmental impacts associated with a project prior to approval (1icense or state permit). A SEPA checklist is completed if required by the state or local agency.

Evaluation:

The agency will determine if a state EIS is required or will issue a determination of nonsignificance. The state agencies consider impacts on the environmental prior to making decisions. If a state approval or permit is required, a SEPA Checklist will most likely be necessary. Contact Mr. Engelmann, 376-7485, for additional information. 


\section{AIR EMISSIONS}

National Emission Standards for Hazardous Air Pollutants (NESHAPs) (radionuclide only) - 40 CFR 61 Subpart $H$.

Any new stationary source or modification of a stationary source of radionuclide emissions is subject to a preconstruction review and approval by the EPA, Region 10. The adjective "stationary" is meant to be applied to the source while it is operational.

Radioactive Air Emissions Program (RAEP) - WAC 246-247

Notice of Construction (NOC) - WAC 246-247-070

All new and modified sources of radionuclide emissions are subject to a preconstruction review and approval by the State of Washington Department of Health (DOH). The definition of a modification in WAC 246-247-070 (2) is, "addition to, enlargement, replacement, or alteration of any process or source which will significantly change potential emissions." "Potential to Emit" is defined as the maximum rate of release of radionuclides from an emission unit, assuming no emission control equipment is present but operations are otherwise normal. The determination of "Potential to Emit" is calculated utilizing one of the following methods:

- Multiply the annual possession quantity of each radionuclide by the release fraction for that radionuclide depending on its physical state (40 CFR 61, Appendix D), to determine the level of documentation required to obtain regulatory approval to construct.

- Perform a back-calculation using measured emission rates and in situ measurements of the control equipment efficiencies, as approved by the EPA and $\mathrm{DOH}$; or

- Use an aTternative method approved by EPA and the DOH.

If the calculated Committed Effective Dose Equivalent (CEDE) to the maximally exposed individual (MEI), caused by the emissions, is calculated to be more than 0.1 millirem (mrem) per year, an NOC must be submitted to DOH for approval. Also, addition to, enlargement, modification, replacement, or alteration of emission control equipment which will significantly change potential emission or dose to the public will require Best Available Radionuclide Control Technology for emission control pursuant to WAC 46-247-070 (3). If the CEDE to the MEI, caused by the emissions, is less than 0.1 mrem per year, a less detailed notification must be submitted to $\mathrm{DOH}$ for approval prior to construction. 
Registration of Source - WAC 246-247-050

The Effluent Information System/Onsite Discharge Information System (EIS/ODIS) is an annual report provided to DOE per DOE Order 5400.1. If a source is listed in the EIS/ODIS, it must be registered with the DOH. The basis for determining if a source must be listed in the EIS/ODIS, and thus requiring registration, is the WHC criteria for record sampling, 7 isted in WHC-CM-7-5, Section 2.5.4, paragraph 3 .

\section{General Regulations For Air Pollution Sources - WAC 173-400}

\section{New Source Review (NSR) Appiicability - WAC 173-400-050}

An NOC is a written application to permit construction of a new source or modification of an existing source. The application describes the proposed design, assesses potential impacts to the public and environment, and provides an assessment of Best Available Control Technology. An NOC is required as a result of two regulations. Sources subject to WAC 173-400 (including 40 CFR 60 and 40 CFR 61 sources) and WAC 173-460 may require preparation of an NOC for preconstruction approval by the appropriate state or local agency.

\section{Source Registration - WAC 173-400-100}

Any source listed must register with Ecology.

\section{Controls for New Sources of Toxic Air Pollutants - WAC 173-460}

The sequence of questions and requirements during an analysis regarding the applicability of WAC 173-460 includes:

1. Will the source be emitting Toxic Air Pollutants (TAPs) other than nonprocess fugitive emissions in a significant quantity?

2. Does the source fall into one of the source categories listed?

3. Is the source exempt?

4. Is this a "new source" of TAPs?

5. Best Available Control Technology for Toxics (T-BACT) is required for sources for which there are increases in TAPs or TAPs not previously emitted.

6. Reasonably Available Control Technology for Toxics (T-RACT) is required for the TAPS, for which the rate of emissions will decrease or stay the same due to the project. 
Prevention of Significant Deterioration - WAC 173-400

Any increased emission of criteria pollutants from a new or modified source may trigger a major modification as defined by 40 CFR 52.21. Expected increases must be considered in conjunction with total Hanford Site emissions. Preconstruction approval may be required by Ecology. The criteria pollutants include:

- Carbon monoxide

- Nitrogen oxides

- Sulfur dioxides

- Particulate matter and PM-10

- Ozone (volatile organic compounds)

- Lead (elemental)

- Fluorides

- Sulfuric acid mist

- Total reduced sulfur compounds (including $\mathrm{H}_{2} \mathrm{~S}$ )

- CFC's 11, 12, 113,114, 115

- Halons 1211, 1301, 2402

- Municipal waste combustor (MWC) acid gases, MWC metal and MWC organics.

If an NOC is required, the amount of the criteria pollutants must be reported in that NOC (see NOC section).

Evaluation:

Contact Mr. J. J. Luke, Air and Water Permitting, at 376-8629 to arrange additional analysis of the air emissions. In addition, ambient air monitoring may be required. Mr. A. R. Johnson of Environmental Engineering Studies coordinates this work for WHC. Mr. Johnson can be reached on $372-3056$.

\section{SOIL COLUMN WASTE WATER DISPOSAL}

Approval of engineering reports, plans and specifications and operating and maintenance manual - WAC 173-240

Prior to construction or modification of those domestic or industrial wastewater facilities requiring Ecology wastewater discharge permits, engineering reports, plans and specifications for the project must be submitted to and approved by Ecology. Operation and maintenance manuals must be submitted prior to completion of construction.

\section{Evaluation:}

A review of Project L-070 documentation (e.g., drawings and specifications) may be required by Ecology for informational purposes. A waiver by this agency may be necessary for the collection system. To obtain more information, call Mr. S. J. Skurla, 372-1102, or Mr. J. E. Turnbaugh, 372-2096. 


$$
\begin{array}{r}
\text { WHC-SD-LO70-PMP-001, Rev. } 0 \\
93-P 0 C-078 \\
88110-R J S-93-129 \\
\text { Page } 10 \text { of } 11
\end{array}
$$

\section{DANGEROUS WASTE}

Dangerous Waste Permit - WAC 173-303

Facilities that treat, store or dispose of regulated dangerous waste must obtain the necessary dangerous waste permits. Determination of whether a waste is a regulated dangerous waste must be done in accordance with WAC 173-303-070 designation procedures. Existing Hanford Facility Treatment, Storage, and Disposal (TSD) units are receiving permits in accordance with schedules and procedures identified in the Tri-Party Agreement. New Hanford Facility TSD units that are not identified in the Tri-Party Agreement will require development of a permitting plan to detail the strategies and schedules to be used for development of the necessary dangerous waste permits. This plan must be developed early in the project development phase.

Strategies and schedules to be used for development of the necessary dangerous waste permits for new TSD units will need to be discussed with the appropriate regulatory agencies to gain their concurrence.

\section{Evaluation:}

All waste materials, associated piping and contaminated equipment shall be disposed of or decontaminated in accordance with the WHC Environmental Compliance Manual, WHC-CM-7-5, Section 7.0. For questions regarding compliance, please contact Mr. E. H. Smith of Regulatory Analys is on 376-0234.

\section{ALL MEDIA}

\section{Cultural Resource Review - 36 CFR 800}

A Cultural Resource Review shall be performed prior to initiating any potential surface-disturbing activities onsite, or if any modifications are planned for any facility with the potential for inclusion on the National Historical Register. Contact Ms. M. K. Wright, 372-1791, PNL.

\section{Evaluation:}

A Cultural Resources Review was conducted and monitoring of excavations by an archaeologist will be required for this activity (1etter HCRC \#91-300-019, PNL).

\section{Excavation Permit - 36 CFR 800}

An Excavation Permit is required prior to initiating any potential surfacedisturbing activities onsite.

\section{Evaluation:}

An Excavation Permit will be required for this project. Contact

$\mathrm{Mr}$. K. A. Gano, 373-4949, Environmental Compliance Support. 


$$
\begin{array}{r}
\text { WHC-SD-L070-PMP-001, Kev : } 0^{*} \\
\text { 93-P0C-078 } \\
88110-\text { RJS-93-129 } \\
\text { Page } 11 \text { of } 11
\end{array}
$$

\section{Endangered Species Approval - 50 CFR 402.6}

A site assessment should be made to determine whether any planned activities have the potential to disturb any critical habitat utilized by threatened and endangered species.

Evaluation:

A biological survey was completed. The conclusions included that violation of the Migratory Bird Treaty Act would not be anticipated if no trees or shrubs are uprooted. However, if trees or shrubs are to be uprooted, an additional survey must also be conducted in April or May 1994 (1etter, BR\#93-WHC-028, PNL).

Preoperational Monitoring of Facilities, Sites, and Operations DOE Order 5400.1

Note: For more information see WHC-CM-7-5, Section 5.0, 5.4.2.1.g \& $\mathrm{h}$; Section 8.0, 8.5.1.7; and Section 9.0,9.3.1.3.

An environmental study shall be conducted prior to start-up of a site, facility, or process which has the potential for significant adverse environmental impact. This study should begin not less than one year and preferably two years prior to start-up to evaluate seasonal changes. This study precedes the conceptual design report and can include data acquired in the site selection process, excavation permit process, and NEPA/SEPA process.

Evaluation:

Mr. A. R. Johnson of Environmental Engineering Studies coordinates this work for WHC. Mr. Johnson can be reached on 372-3056.

\section{Radiation Protection Standards - DOE Order 5400.5}

This Order establishes standards and requirements which must be followed with respect to protection of members of the public and environment against undue risk from radiation. The general environmental protection program requirements are established in DOE Order 5400.1. This order requires that al1 DOE sites prepare an Environmental Monitoring Plan. The DOE/RL 91-50 "Environmental Monitoring Plan" includes the DOE/EH-0173T, "Environmental Regulatory Guide for Radiological Effluent Monitoring and Environmental Surveillance," which provides specific guidance regarding environmental monitoring activities. 